\author{
Journal of Hydrology \\ Volume 590, November 2020, 125507 \\ https://doi.org/10.1016/i.jhydrol.2020.125507
}

\title{
Representing heterogeneity of fluvio-deltaic aquifers in models of groundwater flow and solute transport: a multi-model investigation in the Bengal Basin
}

\author{
${ }^{*}$ Mohammad A. Hoque ${ }^{1}$ and William G. Burgess ${ }^{2}$ \\ ${ }^{1}$ School of the Environment, Geography \& Geosciences, University of Portsmouth, Portsmouth PO1 3QL, \\ UK \\ ${ }^{2}$ Department of Earth Sciences, University College London, Gower Street, London, WC1E 6BT, UK
}

*Email: mo.hoque@port.ac.uk; Tel: +44 (0) 2392842453 (ORCID: 0000-0002-8271-6760)

\begin{abstract}
Groundwater in alluvial terrain, supporting much of the global requirement for irrigation and domestic water, is at risk of sustained water level decline and/or contamination over large areas. In southern Bangladesh excessive arsenic (As) in shallow groundwater has led to deeper groundwater becoming the preferred alternative source of potable water. The vulnerability of deeper tube-wells to As breakthrough from shallow levels can be assessed using groundwater modelling, but representation of alluvial aquifer heterogeneities in large-scale groundwater models presents a challenge; what level of complexity is required? To assess the optimum level of complexity necessary in models of groundwater flow and solute transport in the Bengal Aquifer System (BAS), we explore a range of representations of the lithological heterogeneity using a multi-modelling approach. We use an array of geological information including drillers' $\operatorname{logs}(\mathrm{n}=589)$ and hydrocarbon exploration data $(\mathrm{n}=11)$ across an area of $5000 \mathrm{~km}^{2}$ as a basis for alternative representations of upscaled aquifer heterogeneity, characterising hydrogeological structure in a series of five groundwater models at increasing levels of complexity. We rank the models by comparing model outcomes of travel time with available data on groundwater age based on ${ }^{14} \mathrm{C}$. The results demonstrate the importance of spatial heterogeneity and suggest the significance of incorporating vertical heterogeneity in model representations of the Bengal Aquifer System and similar spatially extensive fluviodeltaic aquifers.
\end{abstract}


Keywords: Groundwater model, Hydraulic conductivity, arsenic transport, Bengal Aquifer System, Bangladesh, Hydrostratigraphy

\section{Introduction}

Groundwater from sedimentary aquifers worldwide sustains irrigation-based agriculture, and provides much of the world's supply of drinking water (Richts et al., 2011; Wada et al., 2014). Groundwater for food production is taken from relatively shallow levels ( $<100 \mathrm{mbgl}$, metre below ground level), commonly at a rate higher than it is replenished by recharge (Tiwari et al., 2009), hence secular depletion of shallow groundwater levels is widely observed (Konikow and Kendy, 2005; Scanlon et al., 2018). Shallow groundwater in alluvial aquifers is also vulnerable to pollution, and there are widespread occurrences of geogenic contamination of shallow groundwater which have enormous consequences for public health, affecting many millions of people (Fendorf et al., 2010; Hoque et al., 2017; Jia et al., 2018; Ravenscroft et al., 2009). Therefore deep groundwater (>100 mbgl), where available, is increasingly seen as an alternative source of water for enabling food security and access to safe domestic supplies. Despite deep groundwater generally being part of a regional flow system (Michael and Voss, 2009a), rates of replenishment may be low, and limited knowledge of the hydrogeology of deep alluvial aquifer systems compromises the understanding and assessment of their groundwater resources. In contrast, basic lithological data is often available in quantity (e.g., Fogg, 1986). In this context, modelling makes a potentially valuable contribution to assessment, but questions arise regarding plausible alternative representations of the aquifer system (Timani and Peralta, 2015) and the level of lithological complexity that should be incorporated to achieve optimum modelling results (Zhou and Herath, 2017). Here we address this question for the extensive and deep Bengal Aquifer System (BAS), applying a range of models with alternative representations of the hydrostratigraphy at increasing levels of complexity achieved through variations in upscaled horizontal and vertical hydraulic conductivity. We then evaluate the success of the models in simulating groundwater ages, generally a more discriminating test than heads and fluxes (Sanford, 2011; Troldborg et al., 2007) to identify the optimum level of complexity in the models in relation to questions of solute transport. In turn, the results shed light on aspects of sustainability of deep groundwater abstraction in this large transboundary aquifer system.

Across the Bengal Basin, prolific Holocene-Pleistocene, fluvio-deltaic aquifers provide abundant quantities of groundwater (Burgess et al., 2010; Ravenscroft, 2003; Ravenscroft et al., 2018). Across the extensive floodplains of rural Bangladesh, hand-pumped tube-wells (HTWs) are used for domestic water supply and motorised pumps abstract groundwater for dry-season irrigation. Groundwater meets almost the entire national water-demand for domestic and industrial water supply and for irrigation, mostly from shallow 
depths (30 to $90 \mathrm{~m}$ ) below ground surface. The discovery of excessive dissolved arsenic in the shallow groundwater (Dhar et al., 1997) in the 1990s raised serious concerns against the exploitation of this resource. However, evidence of the insignificant presence of arsenic below ca 150 to $200 \mathrm{~m}$ (Bhattacharya et al., 1997; DPHE/BGS, 2001) has suggested deep groundwater as a source of 'arsenic-safe' groundwater in the region. Therefore, attention has turned to the potential for this deeper groundwater to provide an arsenic-safe supply in the rural areas (Burgess et al., 2010; Hoque et al., 2011; Michael and Voss, 2008; Mukherjee et al., 2007b; Ravenscroft et al., 2018; Sikdar et al., 2018; Zahid et al., 2015; Zahid et al., 2018). The term 'arsenic-safe' here is defined as water containing $<50 \mu \mathrm{g} / 1$ arsenic, the Bangladesh-India drinkingwater standard. Socio-economic conditions and resource constraints lead this deep groundwater to be the principal and widely-accepted alternative for arsenic-safe water for millions of people in the area (Ahmed et al., 2006). Simultaneously, the provincial towns, also mostly developed on the floodplain areas, have started to develop the deeper groundwater to satisfy the growing demands of urban water supply (Burgess et al., 2010).

Therefore, 'deeper' groundwater has become the principal target for 'arsenic-safe' water supplies throughout southern Bangladesh (Ravenscroft et al., 2009) but the short term sustainability and the longer term security of the resource against invasion of arsenic from shallower depth remain poorly understood. Motivated by the basin-wide approach of Michael and Voss (2008), our aim is to explore the value of regionally-specific data in elaborating regional descriptions of the aquifer to enable sub-basin scale assessments of the sustainability of deep groundwater abstraction. We address the question, to what level of detail can regional, and smaller-scale, hydrogeological information justifiably be represented in models to improve simulations of groundwater flow to deep wells?

Here we consider those characteristics of the aquifer system (i.e., aquifer lithology and hydro-stratigraphy, and the sources of groundwater recharge) which may ultimately determine the security of supply of 'deeper' groundwater against invasion by arsenic. We have assembled data for a component part of the Bengal Basin in south-eastern Bangladesh, interpreted the data in terms of hydrogeological structure, and developed a series of model representations of the aquifer system, sequentially incorporating additional detail in relation to lithological heterogeneities. We use the models to evaluate how the simulated recharge provenance and groundwater travel times vary with alternative representations of the hydrostratigraphy. In the absence of suitable data on deep groundwater heads, we have tested the models against independent indications of groundwater 'age' at selected locations. The purpose is to assess the optimum level of complexity necessary in models of groundwater flow and solute transport in this environment. The relative success of alternative aquifer representations is the key interest, rather than to achieve sequential improvements through calibration. Therefore, comparison of the ability of each model, uncalibrated, to represent groundwater age 
is used to judge the value of incorporating data at sequentially increasing levels of detail, an approach to multi-model testing (Poeter and Anderson, 2005; Troldborg et al., 2007; Zhou and Herath, 2017) which enables the most parsimonious representation to be identified for application to questions of solute transport to depth in the BAS. For this purpose, we focus on average travel times under different deterministic representations, rather than preferential flow under a range of stochastically-generated flow fields (Michael and Khan, 2016), and we have used advective particle tracking to simulate average travel times, The implications for arsenic-safe water supply in the region are subsequently discussed.

\section{Bengal Aquifer System - an overview}

The Bengal basin, a vast trans-boundary sedimentary basin spanning almost all of Bangladesh and the Indian state West Bengal, incorporates the Bengal Aquifer System (Burgess et al., 2010). Before the discovery of groundwater arsenic in the basin, hydrogeological investigations were mostly limited to depths of 100 to $150 \mathrm{mbgl}$ (BADC/MMI/HTS, 1992). Under the current scenario of groundwater exploitation, the term 'deep groundwater' refers to depths >150 mbgl (e.g., DPHE/BGS/MML, 1999) in the BAS which are essentially arsenic-safe, but which are not continuously separated by an aquitard from the shallower levels of the aquifer (Hoque et al., 2017; Mukherjee et al., 2007b; Ravenscroft et al., 2018).

A shallow marine environment prevailed in the area during the Mio-Pliocene time (Gani and Alam, 1999). At the onset of the Himalayan orogeny, the marine clay (Upper Marine Shale - UMS) was subject to uplift, and the depositional regime changed to a fluvio-deltaic setting. The impervious nature of the UMS clay is indicated by its role as a hydrocarbon seal for the gas-fields of the region (Reimann, 1993). Sediments overlying the UMS form what may be best described as an interconnected aquifer system, locally manifested as a series of multi-aquifers due to the ubiquitous distribution of low permeability strata within the predominantly sandy sequence. The entire aquifer system is composed of horizontal to sub-horizontal discontinuous layers of sand, silt, clay, and their mixtures, with the occasional presence of gravel (Hoque et al., 2017). In addition, channel sand bodies associated with river channel migration or avulsion make the aquifer fabric complex and heterogeneous.

With the exception of northwest Bangladesh where depth to the basement is within $200 \mathrm{~m}$ of the ground surface in places, the upper 2000 metres of the sedimentary sequence has the potential to be used as an aquifer system in most parts of the Bengal Basin (Burgess et al., 2010). In terms of economic feasibility and development practices, the uppermost $400 \mathrm{~m}$ is the exploitable aquifer. Although at a local scale, lithostratigraphic detail in the fluvio-deltaic terrain indicates a multi-aquifer system, the lateral continuity of lithological units is limited (Hoque et al., 2017). This lateral discontinuity makes traditional hydrostratigraphical classification (identification of individual aquifers and aquitards, usually layered) contentious in this terrain. A number of hydrostratigraphical models have been proposed by earlier workers in the Bengal Basin. Jones (1985) proposed six separate aquifers to a depth of ca. $1500 \mathrm{~m}$ bgl by analysing 
petroleum drilling log data from the eastern part of the country. UNDP (1982) described the aquifer as having three layers in the upper ca. $100 \mathrm{~m}$, a classification later adopted by MPO (1987), while EPC/MMP (1991) considered the same as a four-layered system in modelling studies of central Bangladesh. These early views of the hydrogeology of Bangladesh were summarised by Ravenscroft (2003), who proposed a stratigraphically-based hydrostratigraphical classification. Due to a lack of data on the extent of the stratigraphical units, their hydraulic continuity, and subtle differences in their hydraulic characteristics, all these recommendations have limitation however.

The concept of a discrete deeper aquifer was based on the evidence for fresh deep groundwater, widely utilized in the coastal regions, which is largely protected from salinity at shallow levels by a silt-clay aquitard at about 100-200 m (DPHE/DANIDA, 2001). BGS/DPHE (2001) adopted the UNDP (1982) classification for the upper ca. $150 \mathrm{~m}$ with the 'upper shallow aquifer' and 'lower shallow aquifer' nomenclature, and added a 'deep aquifer' to the classification for depths greater than $150 \mathrm{~m}$ bgl. A chronostratigraphical classification of the aquifer system: Upper Holocene aquifer, Middle Holocene aquifer, Late Pleistocene-Early Holocene aquifer, and Pleistocene aquifer, has also been proposed (Ahmed, 2003; GWTF, 2002). DPHE/DFID/JICA (2006) supported the view of a discrete arsenic-safe deep aquifer, where the presence of a clay layer at least $10 \mathrm{~m}$ thick separates it from the shallower aquifer but with no consideration for its lateral extent. Distinct differences in hydraulic head (e. g., BWDB, 2005; Harvey et al., 2006; Ravenscroft et al., 2018; Zahid et al., 2018; Zheng et al., 2005), geochemical nature (BWDB, 2005; DPHE/DFID/JICA, 2006; Mukherjee and Fryar, 2008; Ravenscroft et al., 2018; Zheng et al., 2005) and the ages of groundwater (e. g., Aggarwal et al., 2000; Harvey et al., 2002; Hoque and Burgess, 2012; Stute et al., 2007; Zheng et al., 2005) in the shallower and deeper part of the BAS aquifer system might also be used to support the notion of discrete shallow and deeper aquifers. However, a recent study (Hoque et al., 2017) showed that the interleaved pattern of laterally discontinuous layers of silt-clay provides hydraulic separation without the necessity for the deeper (>100 m bgl) part of the aquifer to be physically separated by an aquitard layer from the shallower part.

Some studies have described the whole system as a single aquifer (Michael and Voss, 2009a; Mukherjee et al., 2007b), some as a sequence of discrete aquifers (Shibasaki et al., 2007; Zahid et al., 2015), and some even as laterally distinctive deep aquifer zones (Ravenscroft et al., 2018) but in each case the lack of data has made the interpretation uncertain and/or locally restricted. Lithological discontinuity supports the notion of a single aquifer system on a regional scale with aquifer zones locally distinguished by the regionally discontinuous finer-grained sediment layers (Hoque et al., 2017). Deterministic basin-scale modelling approaches have been applied to simulate average groundwater travel times (Michael and Voss, 2008), and multiple, stochastically-generated representations of the hydraulic conductivity field have been embedded at sub-basin scale, with a focus on the preferential flow components (Michael and Khan, 2016). 
Geological complexities of the Bengal Aquifer System evolved through incisions, erosion, and deposition by the rivers in channel-interfluve settings during the Plio-Quaternary cyclicity in sea-level (Goodbred et al., 2003; Hoque et al., 2014a; McArthur et al., 2008; Umitsu, 1993; Wilson and Goodbred Jr., 2015). These depositional elements, often arranged linearly, are spatially discontinuous but may be vertically stacked. Although typical of any alluvial aquifer, none of these form a laterally continuous layered sequence, but rather they are the primary source of the lithological heterogeneities in the BAS.

The Bengal basin is bounded by hilly areas all around and includes tracts of Plio-Pleistocene sediments surrounded by the Holocene-Recent floodplains of the Ganges, Brahmaputra and Megna rivers, their tributaries and dis-tributaries. The coupling of land surface topography and the aquifer heterogeneities generate a hierarchy of groundwater flow systems (Hoque et al., 2017; Khan et al., 2019; Michael and Voss, 2009a; Ravenscroft et al., 2005; Tóth, 2009) in the basin. Groundwater at shallower depths is younger (a few centuries old) and often contains excessive dissolved arsenic except at the shallowest depth ( $\sim 5 \mathrm{mbgl})$, while deeper groundwater is a few thousand years old and generally arsenic free (Hoque and Burgess, 2012; Hoque et al., 2017).

The BAS, shared by West Bengal of India and Bangladesh, has a tropical monsoon climate with dry winters and wet summers with 2 - 4 m rainfall. Summer rain replenishes the aquifer. Groundwater abstraction for irrigation, domestic and industrial uses since the 1960s has significantly influenced the aquifer hydrology across the region (Harvey et al., 2006; Shamsudduha et al., 2015). The dry-season irrigation abstraction is significantly higher than the domestic abstraction, leading to the Bengal basin being one of the top riceproducing regions in the world. Withdrawal of groundwater for irrigation is from 30 to $90 \mathrm{~m}$ below the ground surface while domestic abstractions come principally from the shallower depths $(<100 \mathrm{mbgl})$ with an increasing proportion from a depth up to $350 \mathrm{~m}$ below the ground.

\section{Methods and Materials}

The modelling focused on a multi-model approach (Poeter and Anderson, 2005) with progressive incorporation of lithological detail first as variable hydraulic conductivity anisotropy in the horizontal direction, and then in the horizontal and vertical directions. An alternative approach would be to develop and compare a set of homogeneous simulations with the same upscaled, anisotropic hydraulic conductivity (K) as each heterogeneous model. The selected approach acknowledges the value in considering alternative plausible models of reality prior to a calibration step (Poeter and Andersen, 2005); these may even be based on alternative conceptual models, although in this case all the models have a common conceptual basis. The models were tested against a set of independently-determined groundwater ages (Aggarwal et al., 2000; Hoque and Burgess, 2012) to identify the most parsimonious representation for application to questions of solute transport (Poeter and Gaylord, 1990) in the BAS, within a transient groundwater flow model. Here 
we outline the data sets, the treatment of lithological data used to derive a range of justifiable hydraulic conductivity fields as the basis for a sequence of hydrogeological models of increasing complexity, and the modelling approach.

\subsection{Study area and data sets}

The study area lies east of the confluence of the River Meghna with the River Ganges in southeast Bangladesh, extending to the coast and bounded by the rugged hilly terrain (in Tripura State of India) in the east (Figure 1, Supplementary Information, hereafter SI, Figure SI1)._Here, 589 drillers' logs were collated for a $5000 \mathrm{~km}^{2}$ area (DPHE/DFID/JICA, 2006). Each log contains information on the dominant grain size of the sediments, i.e., clay, fine sand, medium sand etc. The logs vary in depth from 87 to $375 \mathrm{~m}$ below ground surface, with a median depth of $227 \mathrm{~m} ; 75 \%$ of the logs contain lithological data to a depth of $\geq 258 \mathrm{~m}$ (Figure SI2). The logs were augmented with 11 petroleum exploration lithological logs from the anticlinal crests of subsurface folds in the region (MPO, 1987), which provide a structurally biased data-set for depth to the UMS across the region.

Independently-derived, ${ }^{14} \mathrm{C}$-based, corrected groundwater ages for 19 wells throughout the area, of which 18 are from Hoque and Burgess (2012), and 1 from Aggarwal et al., (2000) were used for comparison with travel times from the groundwater flow model. Among the groundwater ages, 4 relate to groundwater at less than $100 \mathrm{~m}$ depth and the remainder to groundwater deeper than $100 \mathrm{~m}$.

\subsection{Hydrostratigraphical analysis}

Distinction between clay-silt (low permeability material) and sand (high permeability material) is the most important use of the logs, because of the significance for groundwater flow. The logs were coded into 10 lithofacies to generate a consistent dataset based on grain-size (e.g., clay, silty clay to gravel with sand) (Table 1). For the petroleum exploration logs, consideration was given to the dipping angle of strata in the subsurface folds (as of HU/NPD, 2001; Reimann, 1993) before interpolating between points to derive a map of depth to the top of UMS (Figure SI 2).

Two hydrofacies were determined, i.e finer (non-aquifer materials) and coarser (aquifer materials) on the basis of the grain-size coding. The term 'hydrofacies' was originally introduced for relatively homogeneous but anisotropic units that are hydrogeologically meaningful (Poeter and Gaylord, 1990). Here, 'hydrofacies' are designed to indicate the internal heterogeneity arising from lithological variation by introducing a binary distinction between the finer and coarser lithofacies (Figure SI3).

The logs, translated as described into lithofacies and hydrofacies, were interpolated in 3D environment within Rockworks ${ }^{\circledR}$ programme on a grid of $1000 \mathrm{~m}$ x $1000 \mathrm{~m}$ x $2 \mathrm{~m}$. Spatio-vertical variability within the aquifer, in terms of the layering of finer materials potentially separating the shallow and deeper part of the 
aquifer system, was described using the sand to silt-clay ratio to depict palaeo-channel and palaeointerfluvial regions because of their respective sand and clay-silt dominance. Lithological detail was then translated to a description of the hydraulic conductivity, the dominant parameter by which geological variability is represented in models of groundwater flow and solute transport, as described in the following section.

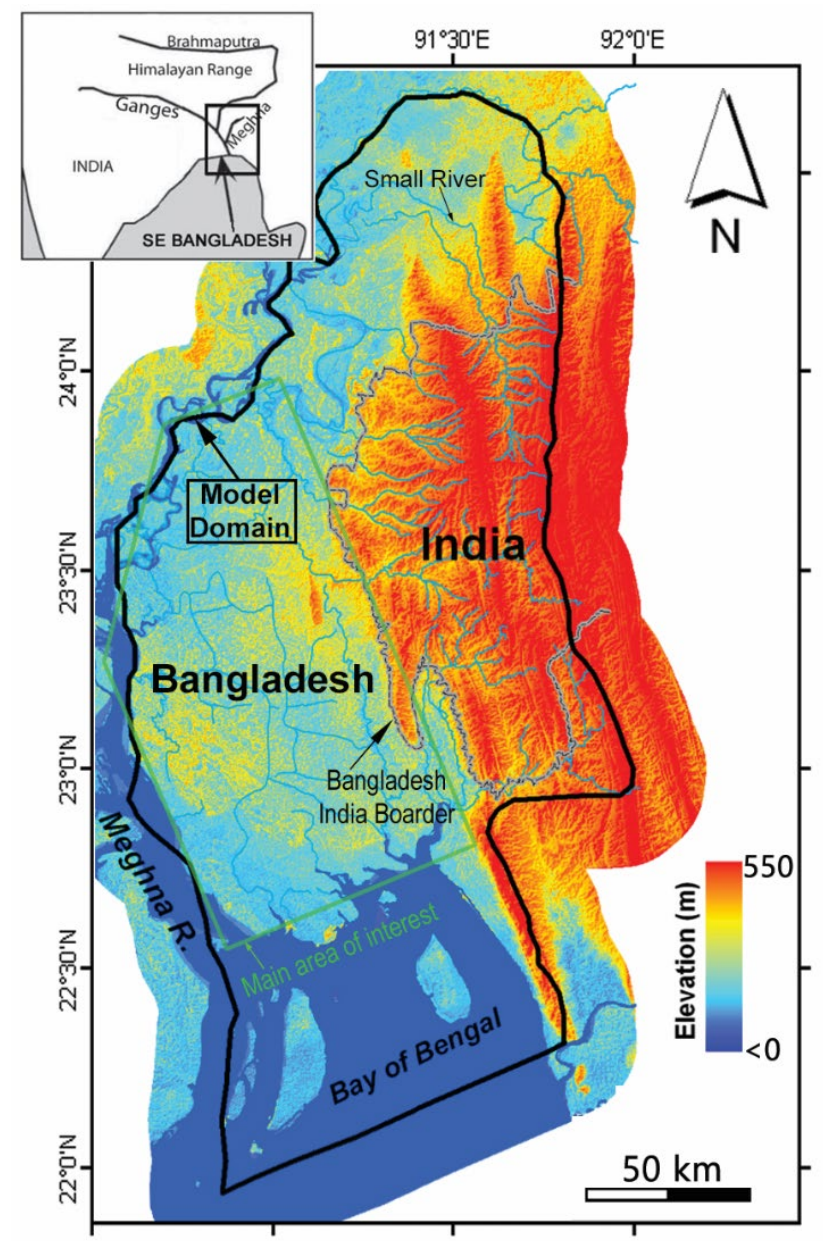

Fig. 1. Geographical boundary of the model study area along with the main area of interest over a digital elevation model (EROS 2002) of the area. The inset map indicates the location of the area on a subcontinental scale.

\subsection{Hydraulic conductivity field}

Hydraulic conductivity can be estimated by various means, in the field by pump-testing aquifers, in the laboratory from core tests, and from lithological data (e. g., Freeze and Cherry, 1979). In the case of regional-scale studies, estimation of hydraulic conductivity using empirical relationships to grain size has been found to reduce uncertainty many times more than other approaches (Nilsson et al., 2007). In the 
current study, the lithological attributes derived from drillers' logs were used to estimate the effective hydraulic conductivity as a means of representing geological variability in the groundwater models. Hydraulic conductivity $(\mathrm{K})$ values for all lithofacies were selected from previous literature on the area (BGS/DPHE, 2001; GWTF, 2002; Michael and Voss, 2009b; Rahman and Ravenscroft, 2003), (Table 1). In a layered system of strata with constant thickness and infinite extent, the direction of highest equivalent hydraulic conductivity $\left(\mu_{\alpha}\right)$ is parallel to layering, and the direction of lowest conductivity $\left(\mu_{\mathrm{h}}\right)$ is perpendicular to layering, with bulk values given by the arithmetic mean (Eq. 1) and harmonic mean (Eq. 2) of the conductivity of the layers respectively (Freeze and Cherry, 1979). These are known as the Wiener bounds, the maximum and minimum possible values of effective hydraulic conductivity (Renard and de Marsily, 1997).

$$
\begin{aligned}
& \mu_{h} \leq K_{\text {eff }} \leq \mu_{\alpha} \\
& \mu_{\alpha}=\frac{\sum K \cdot b}{\sum b} \\
& \mu_{h}=\frac{\sum b}{\sum b / K}
\end{aligned}
$$

Where, $K=$ hydraulic conductivity of a particular lithological unit, and $b=$ thickness of the lithological unit.

In fluvio-deltaic settings, where lithological layers have a limited extent, these idealised relationships may not be valid. Ababou (1996) derived alternative relationships, also applied by Michael and Voss (2009b), describing the effect of low permeability layers of limited extent, assuming the aquifer to be a statistically homogeneous medium:

The effective hydraulic conductivity in any direction $\left(K_{\text {eff }}\right)$ is

$$
\begin{aligned}
& K_{\text {eff }}=\mu_{a}^{\alpha} \mu_{h}^{1-\alpha} \\
& \alpha=\frac{D-l_{h} / l_{i}}{D}
\end{aligned}
$$
3

Where, $\mu_{\alpha}$ and $\mu_{\mathrm{h}}$ are defined in equation 1 and 2; $\alpha$ is a coefficient as defined by equation 4 , which depends on the dimension of the medium and parameters of the statistically homogeneous log-Gaussian-distributed field of hydraulic conductivity (Michael and Voss, 2009b). Here, 
$D=$ space dimension (value 3 for $3 \mathrm{D}$ problems)

$l_{i}=$ correlation length, and

$l_{h}=$ harmonic mean of $\ell_{i}$ in the principal directions of anisotropy

Even with the large number of drillers' logs, spatial mapping of the distribution of the lithologies carries much uncertainty because of the wide spacing of data points. This limits the capacity of the statistical variogram to be predictive, therefore we assumed the system to be log-Gaussian and used the above equations to estimate the effective hydraulic conductivity.

Table 1: Hydraulic conductivity values for different lithofacies are used to estimate the effective hydraulic conductivity (see text).

$\begin{array}{ll}\text { Lithofacies } & \text { Hydraulic conductivity (m/d) } \\ \text { Gravel with sand (gs) } & 120 \\ \text { Coarse sand (cs) } & 95 \\ \text { Medium to coarse sand (mcs) } & 72 \\ \text { Medium sand (ms) } & 50 \\ \text { Fine to medium sand (fms) } & 38 \\ \text { Fine sand (fs) } & 25 \\ \text { Very fine to fine sand (vffs) } & 20 \\ \text { Very fine sand (vfs) } & 12 \\ \text { Silt/ clayee sand / sandy clay (scs) } & 0.397 \\ \text { Clay (c) } & 6.05 \mathrm{e}-5\end{array}$

Poor data coverage leads to uncertainty in the lateral extent of the lithological units, which could range from a few 10 s of metres to a few kilometres as is normal in fluvio-deltaic deposits. To overcome this and encompass all likely extents of lithological units, values for the correlation length, $l_{i}$ were taken to range from 50, 100, 500, and $1000 \mathrm{~m}$. For simplicity, $l_{i}$ was taken as isotropic in the $\mathrm{X}$ and $\mathrm{Y}$ planes, when in reality there may variability in the horizontal. Effective hydraulic conductivity values were calculated for the entire depth of each individual log record, first assuming a single slab (of thickness the total log depth), and second assuming depth-wise slabs $(0-100 \mathrm{~m}, 100-200 \mathrm{~m}$, and 200-300 m). The depth-wise slab thicknesses were considered consistent with the delta development, where the topmost $c a .100 \mathrm{~m}$ of sediments is associated with late Quaternary evolution of the delta (e.g., Burgess et al., 2010; Goodbred et al., 2003). The four values of effective hydraulic conductivity at each $\log$ location (associated with $l_{i}$ values of 50,100, 500, and $1000 \mathrm{~m}$ ) were interpolated using the IDWA interpolator in order to derive a range of hydraulic conductivity fields incorporating increasing detail of hydrostratigraphic complexity (Section 4.2).

\subsection{Groundwater model development}

Groundwater modelling was carried out using the USGS modelling code MODFLOW (Harbaugh et al., 2000), MODPATH (Pollock, 1994), and ZoneBudget (Harbaugh, 1990). A range of transient groundwater 
flow models was developed using the hydraulic conductivity fields described above. All the model representations therefore share common features i.e. model domain, overall geometry, recharge distribution, stresses and also certain hydraulic parameters (specific yield $\left[S_{y}\right]$, specific storage $\left[S_{s}\right]$, porosity $[n])$. These common features are briefly described first, followed by the hydraulic conductivity fields which vary in the models.

\subsubsection{Model domain}

The model region is extensive, about $28,000 \mathrm{~km}^{2}$, much larger than the area in which interest is focussed, to facilitate the consistency with plausible natural boundaries for the deep groundwater flow system (Figure 1). The eastern boundary follows the north-south aligned hills in the Tripura state of India (Figure SI1), while the western and northern boundaries follow alignment of major rivers. The model region is elevated in the eastern part, and slopes westward towards the bounding rivers and the coast. The southern boundary of the model is set around $50 \mathrm{~km}$ offshore from the coast in the Bay of Bengal.

\subsubsection{Boundary condition}

Lateral boundaries in all the models are set as no-flow. The eastern boundary, set at $>50 \mathrm{~km}$ east of the area of interest, coincides with a surface water-divide, considered also to be a groundwater divide as the UMS is reported to be exposed along the fold-crest (Reimann, 1993). The boundaries in the west and north follow major rivers. The model region overlying the Bay of Bengal was defined as a prescribed head above the seafloor, set to the equivalent freshwater head calculated as ' $1.025 \mathrm{x}$ bathymetry', with a no-flow boundary at the southernmost edge of the model. The sea-floor of the Bay of Bengal has low permeability sediments and to constrain the impact of the sub-Bay boundary on the interior of the model we assigned a very low hydraulic conductivity $\left(1 \times 10^{-12} \mathrm{~m} / \mathrm{s}\right)$ to the sediments in the Bay region as previously applied by Michael and Voss (2009a).

The base of the model is taken as the top of the low-permeability UMS, which occurs at variable depth across the region and is realistically defined as a no-flow boundary. The top boundary is assigned a prescribed head equal to ground surface elevation averaged across each model grid (Al-Salek, 1998; EROS, 2002; Rahman et al., 2004), in order to allow recharge and topographically-driven gravitational groundwater flow as proposed by Sanford (2002) and as previously applied in a basin-scale model of the Bengal basin (Michael and Voss, 2009a).

\subsubsection{Discretisation}

The model contains a principal area of interest $c a .10,000 \mathrm{~km}^{2}$ in extent (Figure 1) and up to $c a .350 \mathrm{~m}$ in depth. For the ease of input of 3D attributes (e.g., pumping, hydraulic properties) the models were discretised spatially and vertically. To minimise computational cost lateral grid discretisation was set to $1000 \mathrm{~m}$ in the area of interest, and $5000 \mathrm{~m}$ in areas beyond (Figure 2). In a transition zone a grid smoothing factor of 1.5 (Harbaugh et al., 2000) is maintained for computational stability. Vertically, eight model units 
of varying thickness and vertical discretisation (Table 2) facilitate adequate representation of the depthdependent attributes, but lithological variability is maintained as a 4-layer system (i.e., 0-100, 100-200, 200-300 and >300 $\mathrm{mbgl}$ ).

The modelling covers a long duration of time, 48045 BC to 2008, in order to derive the backward travel time of deep groundwater from its recharge origin, with groundwater reported to be 10 to 20 ka years old in places (Aggarwal et al., 2000). The end time of the models was set to 2008 to comply with the groundwater age data (Hoque and Burgess, 2012). It is assumed for the purposes of the modelling that the geological structure remains fixed throughout this time; the validity and implications of this assumption are considered in the Discussion. To incorporate increasing quantities of groundwater abstraction from the 1960s, and seasonal variations in groundwater pumping rates, the model incorporates 1960 to 2008 as a period of groundwater development using 53 stress periods ranging in length from 5 years up to 1980, to one third of a year from 1980 to 2008 (Table SI 1).

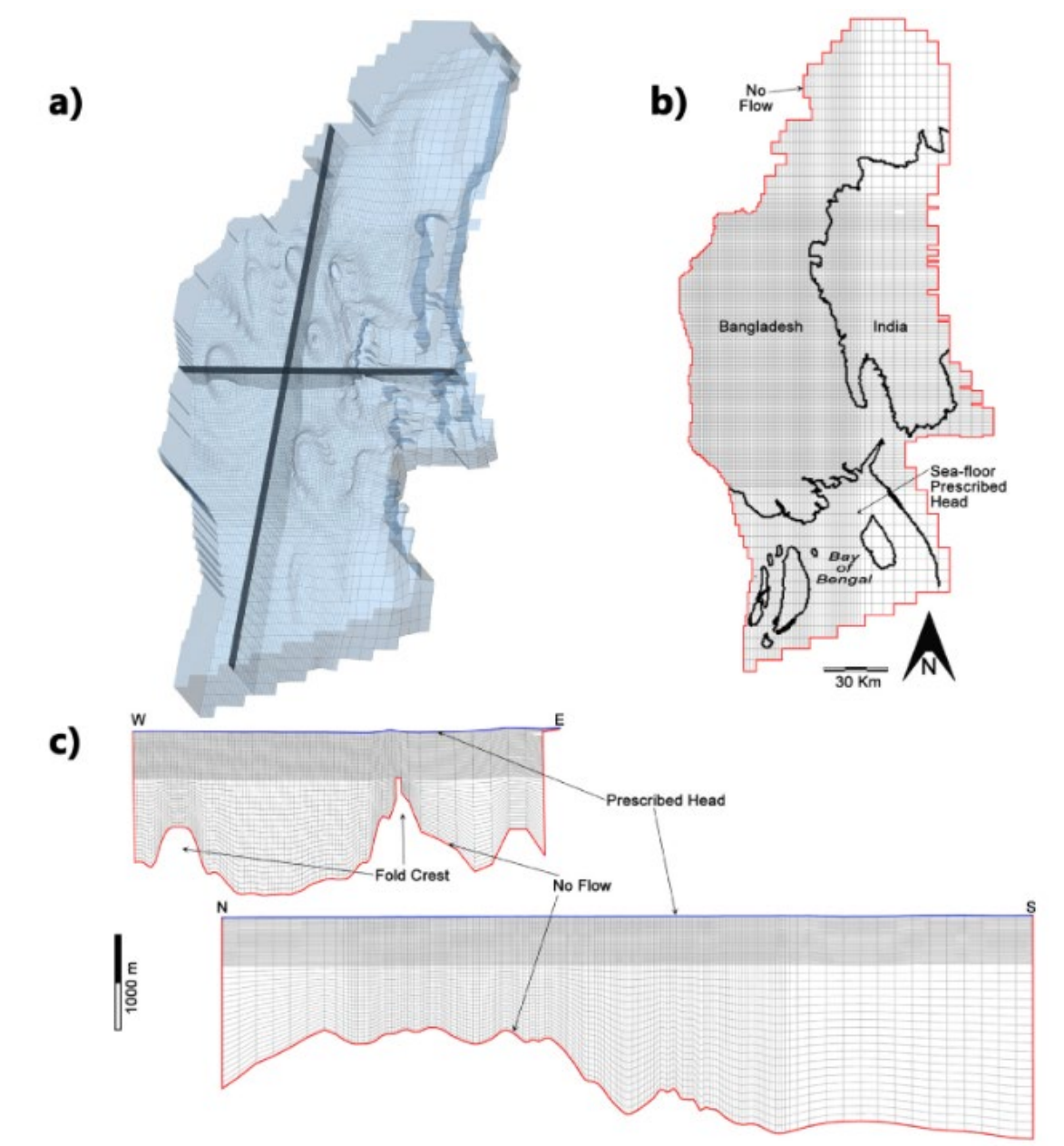

Fig. 2. Model geometry, grid, and boundary conditions locations. a). Three-dimensional view of model domain. Vertical exaggeration is 20x. Bottom elevation of the model is associated with the folding-induced, uneven surface of the UMS. b) Top view of model grid. Boundary between India and Bangladesh, and coastline are shown for reference. c) Vertical cross-sections, note grid discretization decreases with depth. 
Table 2: Vertical discretisation of the models' unit along with specific yield (Sy), specific storage (Ss) and effective porosity (n) values used in the models. Note that all the layers in the model are simulated as 'convertible' aquifers, therefore the code assigns Sy or Ss depending on the hydraulic context i.e. unconfined or confined conditions respectively.

\begin{tabular}{|c|c|c|c|c|c|c|}
\hline Unit & $\begin{array}{l}\text { Hydrostratigraphy/ } \\
\text { hydraulic layer }\end{array}$ & $\begin{array}{l}\text { Maximum } \\
\text { thickness } \\
\text { (m) }\end{array}$ & $\begin{array}{l}\text { Number } \\
\text { of vertical } \\
\text { cells }\end{array}$ & $\begin{array}{l}\text { Specified } \\
\text { yield }\left(\mathbf{S}_{\mathbf{y}}\right)\end{array}$ & $\begin{array}{l}\text { Specific } \\
\text { storage } \\
\left(S_{s}\right) m^{-1}\end{array}$ & $\begin{array}{l}\text { Effective } \\
\text { porosity } \\
\text { (n) }\end{array}$ \\
\hline 1 & Layer 1 & 1 & 1 & 0.06 & 1E-3 & $\mathbf{0 . 3 0}$ \\
\hline 2 & & 49 & 4 & 0.06 & $1 E-4$ & 0.25 \\
\hline 3 & & 50 & 5 & 0.06 & $1 \mathrm{E}-4$ & 0.25 \\
\hline 4 & Layer 2 & 100 & 10 & 0.06 & 1E-4 & 0.25 \\
\hline 5 & Layer 3 & 100 & 10 & 0.1 & $1 E-5$ & 0.20 \\
\hline 6 & Layer 4 & 100 & 10 & 0.1 & $1 E-5$ & 0.20 \\
\hline 7 & & 100 & 10 & 0.1 & $1 E-5$ & 0.20 \\
\hline 8 & & 2000 & 20 & 0.1 & $1 E-5$ & 0.20 \\
\hline
\end{tabular}

\subsubsection{Stresses}

Stresses represent the addition or removal of water from the model domain. Under natural conditions, water enters the groundwater system as recharge, and discharges to rivers, lakes and sea, and by evapotranspiration. The natural setting is disrupted by groundwater abstraction at wells. Natural recharge and discharge are allowed from the model by reference to the prescribed heads at the top boundary of the model, which is considered to be appropriate given the widespread availability of water near the surface throughout the year and as the principal interest of the modelling lies in the deeper levels of the aquifer. Groundwater abstraction at water wells is estimated and represented in following ways:

Irrigation abstractions: Spatial data on the irrigation well locations and the amount of pumping is not detailed, and the very large numbers of wells located over the model domain make it impossible to represent wells individually. Data on the extent of irrigated land area were compiled from BADC (2003) for individual upazila (sub-districts) in the model domain, and were projected backward and forward in time to estimate trends in irrigation abstraction (Figure 3) using generalised trends (Figure SI 5), (BADC, 2003; Bhuiyan, 1984; Rahman and Ravenscroft, 2003; Wahid et al., 2007). It is assumed that the spatial pattern of irrigated land was similar (as of 2003) throughout this time and only the amounts of abstraction have changed over time (Figure SI4). The irrigation abstraction rate is set at $1 \mathrm{~m} /$ year equivalent depth of water per season of abstraction (e.g., Wahid et al., 2007; WARPO, 2000). The depth of the irrigation-well abstractions varies spatially in the model, to represent the field situation. No irrigation abstraction from groundwater was applied in Tripura of India (the eastern side of the model domain, Figure 1) as agriculture in that region relies on surface water (WWF and DoA, 2007).

Household and industrial abstraction: Household abstractions were estimated based on per-capita consumption using population data extracted from the global population model LandScan 2006 (ORNL, 2008) (Figure 3), assumed to be the true distribution of population in 2006. Information on the growth of population (BBS, 2004) was used to estimate the total household, industrial, and drinking water abstractions over time.

In the model area, nearly $100 \%$ of the population rely on groundwater for their drinking water, at a rate taken as 5 1/day/person. The dependency on groundwater started in the 1960s and by the 1990s had reached 
100\%. Domestic use (70 1/day/person), is <30\% from groundwater (http://faostat.fao.org/ accessed on 21 July 2008), met from shallow hand-pumped tubewells $(<100 \mathrm{~m})$ bgl. The estimated per-capita abstraction was used to calculate the total abstraction of water for 2006, extrapolated to other years and stress periods by reference to that year.

Abstraction by high-yielding wells (Figure 3) at the provincial towns (DPHE, personal communication) was estimated using average operation time ( $c a .10$ hours) multiplied by the discharge capacity ( $20 \mathrm{l} / \mathrm{s})$ of the well. Similarly, 600 deep hand-pumped wells in the model area (DPHE/DFID/JICA, 2006) are included as abstraction points in the model to simulate deep household abstraction. As the number of wells increases with time, the rate of abstraction for these wells was increased to accommodate the increased withdrawal. It is assumed that each deep tube-well meets the demand of drinking water for 30 families with 5 members in each i.e. totalling $750 \mathrm{l} /$ day as a conservative estimate; for comparison, in a densely populated area in central Bangladesh deep tube-wells were found to provide ca. 2500 1/day (van Geen et al., 2003). In the models, the abstraction amount equivalent of 1600 wells is considered to start operation during 1996 (K. M. Ahmed, Personal Communication), with year on year increase of $10 \%$ up to 2008. Abstraction in Tripura is confined to shallower depths $(<50 \mathrm{mbgl})$ and in some cases people depend on dug wells (WWF and DoA, 2007).

\subsubsection{Hydrogeological parameterization}

Five representations of the heterogeneity of hydraulic conductivity were developed (W1-W5), incorporating increasing detail of hydrostratigraphic complexity (section 4.2). Values of specific storage $\left(\mathrm{S}_{\mathrm{s}}\right)$ generally range from $10^{-5} \mathrm{~m}^{-1}$ (sandy gravel) to $10^{-2} \mathrm{~m}^{-1}$ (tight clay) (Domenico and Schwartz, 1998). Pumping tests in the study region have found confined storativity (S), the product of aquifer thickness and $\mathrm{S}_{\mathrm{s}}$, to be in the range of 8.7E-4 to 1.9E-3 at depths greater than $200 \mathrm{~m}$ (BWDB, 2005). Specific yield $\left(\mathrm{S}_{\mathrm{y}}\right)$ values range from $0.02-0.05$ over much of the Basin (MPO, 1987). The spatial variation of $\mathrm{S}_{\mathrm{y}}$ and $\mathrm{S}_{\mathrm{s}}$ in this sand-dominated terrain is not expected to be great (Domenico and Schwartz, 1998). Therefore, single values of $S_{y}$ and $S_{s}$ are used for individual model layers (Table 2). Similarly, single values of effective porosity, required for estimation of groundwater velocity and travel-times, are assigned for each layer (Table 2).

\subsubsection{Multi-model comparison}

The models were first applied, uncalibrated, to simulate the shallow head data available for the region. They were then ranked using linear regression to measure their success in replicating the groundwater age data available, which are concentrated in the deeper parts of the aquifer. For this purpose, groundwater travel times were established, from points in the aquifer system with groundwater age determinations to the source of recharge, by backward particle tracking using MODPATH in all the model representations. 

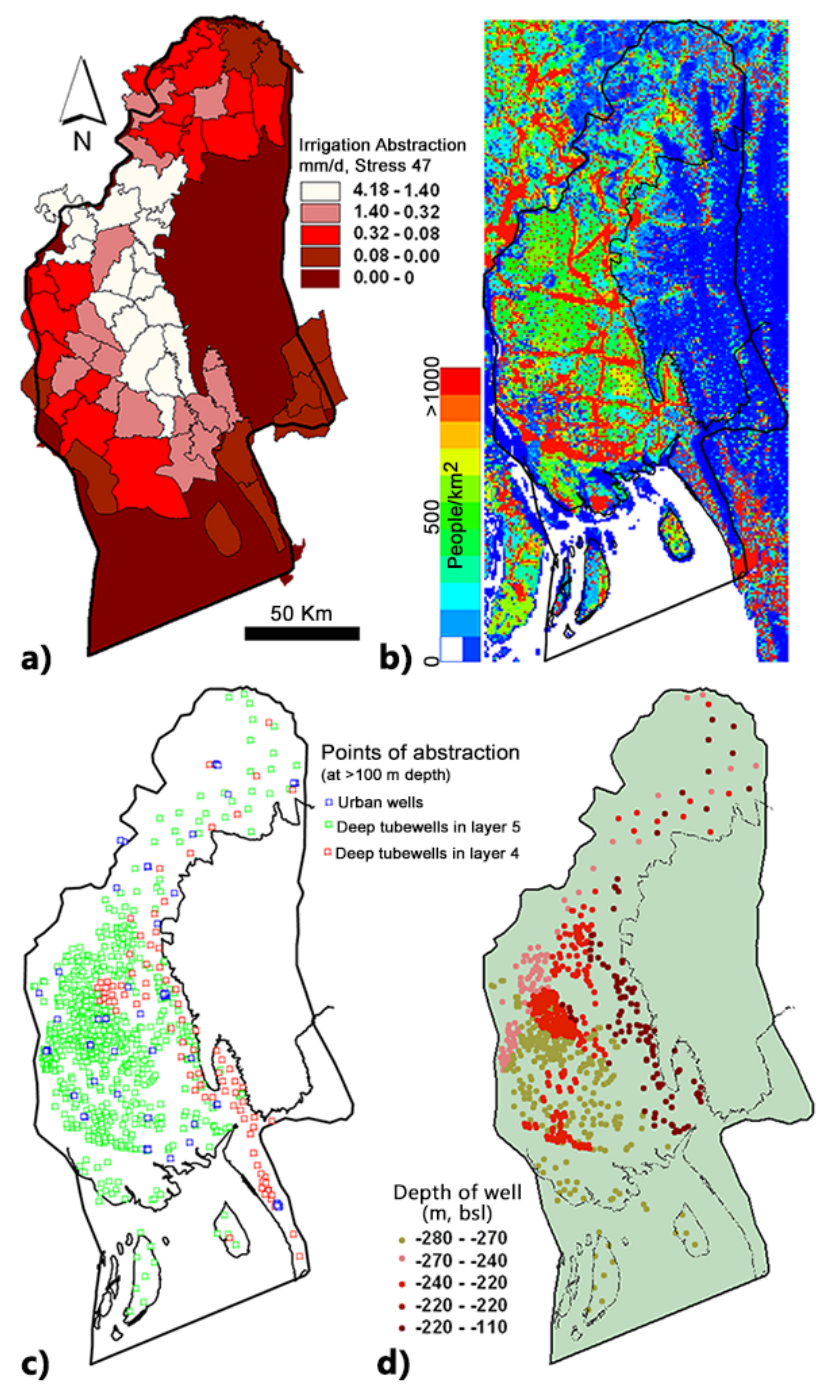

Fig. 3. Estimated a) irrigation abstraction ( $\mathrm{mm} /$ day) for the stress period 47 (peak irrigation time of the year 2005-2006), and b) LandScan global population-model derived population distribution in the area used for estimation of groundwater abstraction from shallower depth of the aquifer; c) Points of abstraction used in the model, and d) depth of the wells as included in the models.

\section{Results}

\subsection{Hydrostratigraphy}

Lithofacies and hydrofacies modelling to a depth of $250 \mathrm{~m}$ illustrates the distribution of lithologies in 3D (Figure 4) and indicates the overall dominance of sand (ca. 60\%) over silt-clay (ca. 40\%). The distribution of lithologies is patchy and neither regional nor sub-regional layers are formed, suggesting instead a single aquifer which is physically connected throughout the model domain. The finer lithologies are dominant in the northwest and southwest of the area, however, between the shallower and deeper parts of the aquifer. 
Coarser lithologies dominate the sequence, particularly in the mid-north part and at deeper levels throughout the area; in places, stacking of the coarser sand bodies is evident (Figure SI5). The concept of discrete regional aquifers, largely separated by a silt-clay aquitard (e.g., DPHE/DANIDA, 2001; UNDP, 1982), is not apparent in the hydrostratigraphical analysis.

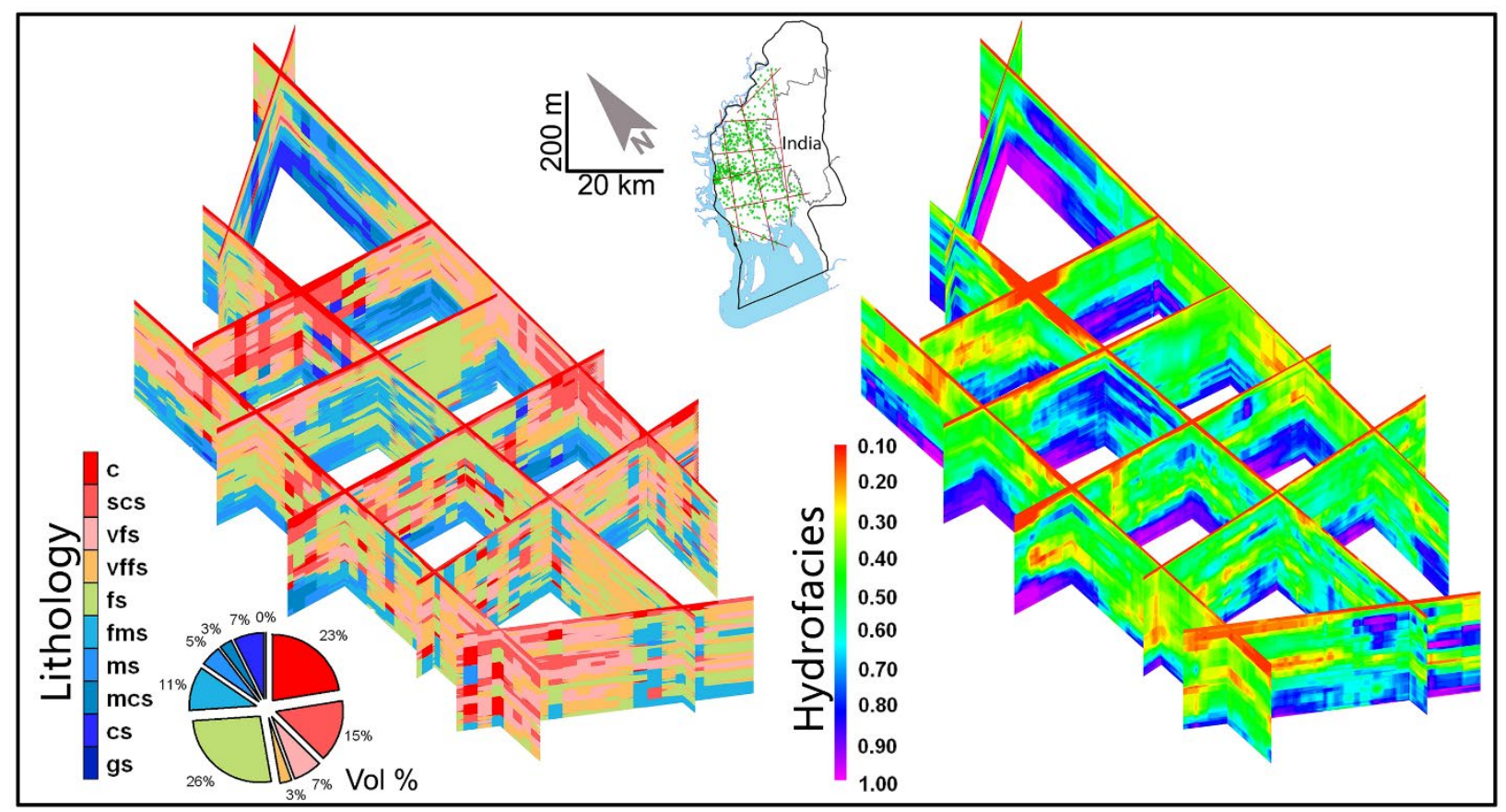

Fig. 4. Fence diagrams based on litho-facies modelling - using RockWorks 2002 with IDWA algorithm with a grid size $1000 \mathrm{~m} \times 1000 \mathrm{~m} \times 2 \mathrm{~m}$. The pie chart indicates the modelled volume $(\%)$ of different lithologies. Fence faces are shown in the inset map; ' 1 ' in hydrofacies code indicates coarser sand while ' 0.1 ' indicates for clay.

The base of the Bengal Aquifer System, taken as the top of the marine clay, the UMS, is exposed along the hills in the Tripura region of India. Across the model domain, it varies in elevation from $200 \mathrm{~m}$ above sea level (masl, metre above sea level) to $2600 \mathrm{~m}$ below sea level (Figure 5).

The entire sequence above the UMS is composed of clay, silt, sand, and their mixture, assembled through fluvio-deltaic deposition. The sequence is spatially and vertically heterogeneous (Figure 5). In some areas low permeability materials are more widely extensive and may confine discrete aquifers locally; in other areas, sand bodies are locally embedded within the low-permeability materials, and form, bounded, leaky aquifers. The analysis of sand to silt-clay ratio demonstrates the occurrence of curvilinear features of relatively thin clay and silty-clay sediments, their number and direction being variable with depth (Figure SI6). On this basis, hydraulic conductivity fields (section 4.2) were generated for three slabs of $100 \mathrm{~m}$ thickness to a cumulative depth of $300 \mathrm{~m}$ to capture the lithological variation for use in the models. 


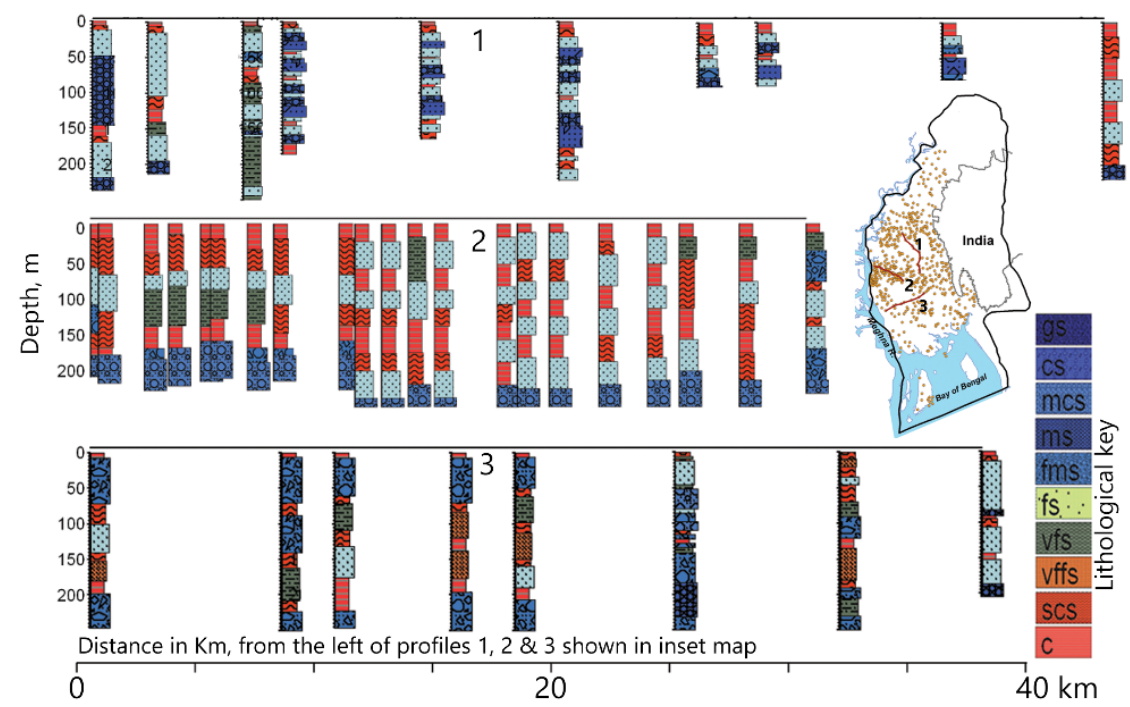

a) The spatial variability in lithofacies
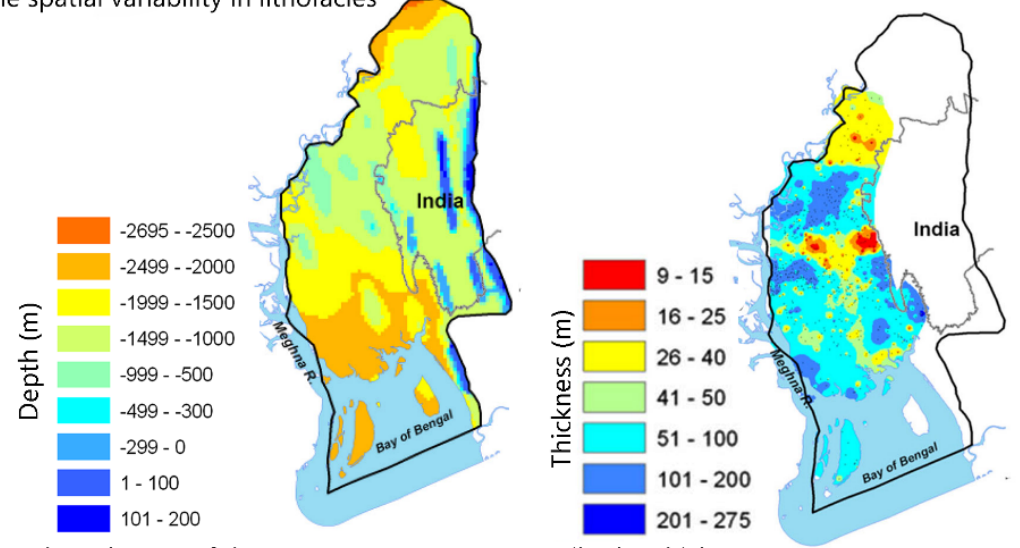

b) Depth to the top of the UMS

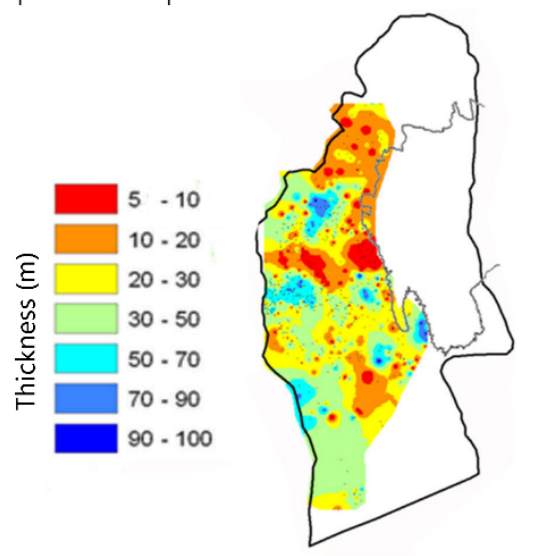

Silt-clay thickness over 0-300 m

C) Silt-clay thickness over $100-200 \mathrm{mbg}$

Hydraulic anisotropy variation over $100-200 \mathrm{mbgl}$

Fig. 5. Lithological variability; a) (top panel) the sections indicate the spatial variability in lithofacies; b) depth to the top (reference, relative to sea-level) of the UMS, the hydraulic basement of the aquifer system in the area and the cumulative thicknesses of silt-clay layers over 0 to $300 \mathrm{~m}$ depth. c); Cumulative siltclay thickness between 100 and $200 \mathrm{mbgl}$ and the conversion of lithological heterogeneity into hydraulic anisotropy $(\mathrm{Kh} / \mathrm{Kz})$ showing the comparable spatial variation of the two. 


\subsection{Hydraulic conductivity}

Hydraulic conductivity is a means of representing geological variability and thereby aquifer heterogeneity in groundwater models (de Marsily, et al., 2005). The data could be assembled in many different ways. Here, building on the hydraulic conductivity variability inferred from the lithological logs, values for effective hydraulic conductivity were calculated using equations 3 and 4 over four depth intervals (the entire $\log$ thickness and 0-100 m, 100-200 m and 200-300 m) and applying a range of correlation lengths (i.e. length scale of statistical homogeneity), $l_{i}(50,100,500,1000 \mathrm{~m})$ at each model grid. The following different but plausible representations of the BAS hydraulic conductivity fields (W1-5) incorporate lithological heterogeneity at increasing levels of complexity (Figure 6) for use in the groundwater flow models.

Representation W1: A single homogeneous anisotropic aquifer with $\mathrm{K}_{\mathrm{h}} / \mathrm{K}_{\mathrm{z}}$ of $10^{4}$ as determined by the lithological analysis. Note that this regional value of median anisotropy is the same as found by Michael and Voss (2009b) at whole-basin scale, whereas Khan et al (2019) have identified a lower value in the south-west of the basin.

Representation W2: A single layer (vertically homogeneous), heterogeneous aquifer with spatially varying anisotropy in hydraulic conductivity as determined by lithological analysis, and with correlation length, $l_{i}=500 \mathrm{~m}$ following Michael and Voss (2009b).

Representation W3: A multi-layer, heterogeneous aquifer with spatially and vertically varying anisotropy in hydraulic conductivity as determined by lithological analysis, and with a minimum correlation length, $l_{i}=100 \mathrm{~m}$ for each layer.

Representation W4: As for W3, with correlation length, $l_{l}=500 \mathrm{~m}$ for each layer.

Representation W5: As for W3, with correlation length, $l_{i}=100 \mathrm{~m}$ (upper layer), $500 \mathrm{~m}$ (middle layer) and $1000 \mathrm{~m}$ (lower layer) respectively, to reflect increasing drainage density and hence decreasing lateral continuity from the Pleistocene to the Holocene (e.g., Hoque et al., 2017).

Effective hydraulic conductivity values are greatly influenced by the presence of low permeability materials and the spatial extent, i.e. the correlation length $\left(l_{i}\right)$, of the low permeability materials is more significant than the thickness (Michael and Voss, 2009b). It is seen that for reasonable correlation lengths, spatial patterns of effective hydraulic conductivity bear a similarity to spatial patterns of lithological heterogeneity expressed as cumulative silt-clay thickness (Figure 5c).

In all the models, layer-4, lying $>300 \mathrm{~m}$ below the surface, is taken to be homogeneous in hydraulic conductivity with $\mathrm{K}_{\mathrm{h}} / \mathrm{K}_{\mathrm{z}}$ anisotropy of $10^{4}$. 

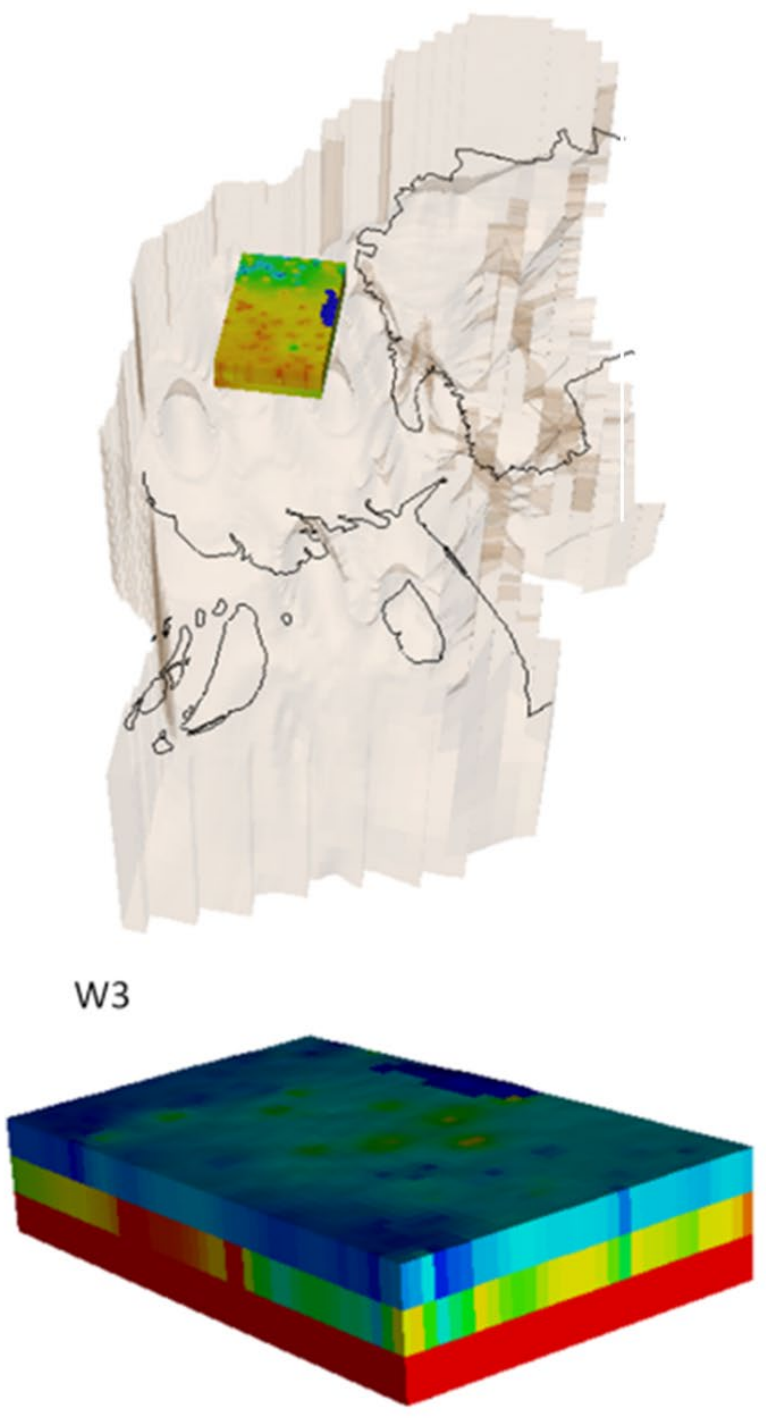
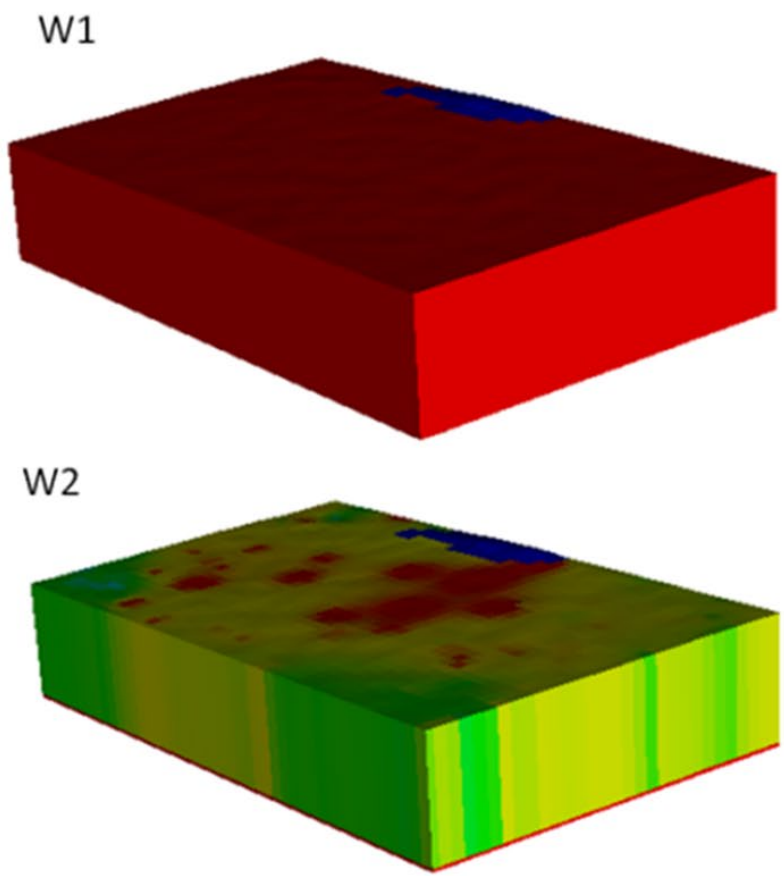

W4
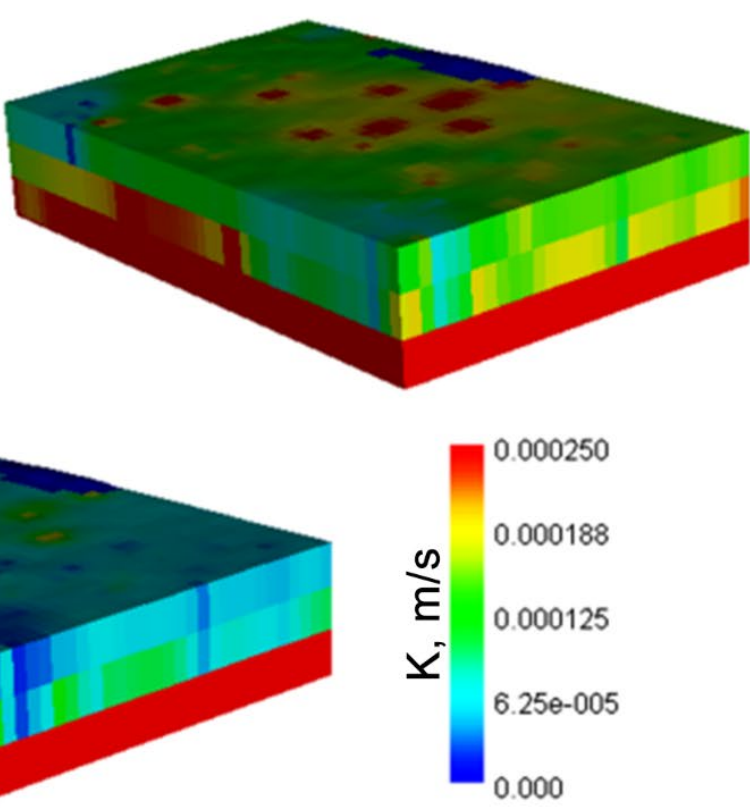

Fig. 6. Alternating hydrogeological representations of the aquifer (to $300 \mathrm{~m} \mathrm{bgl}$ ) in terms of hydraulic conductivity (right colour bar, $\mathrm{m} / \mathrm{s}$ ). Left panel represents study area in 3-D and shows sample area, which is used for depiction of different representations. 


\subsection{Model outcomes and comparison}

The objective of the current research requires evaluation of the large-scale regional models (with grid volume no less than $1000 \times 1000 \times 10 \mathrm{~m}^{3}$ ) against limited head data and independently-derived estimates of groundwater age, both measured at point locations (with screen volume $\sim 0.03 \mathrm{~m}^{3}$ ), to enable ranking of the models according to their performance. Because of the large discrepancies between simulation and field data representation, a large range of error was allowed in the model performance analysis. We rationalise this further in Discussion section.
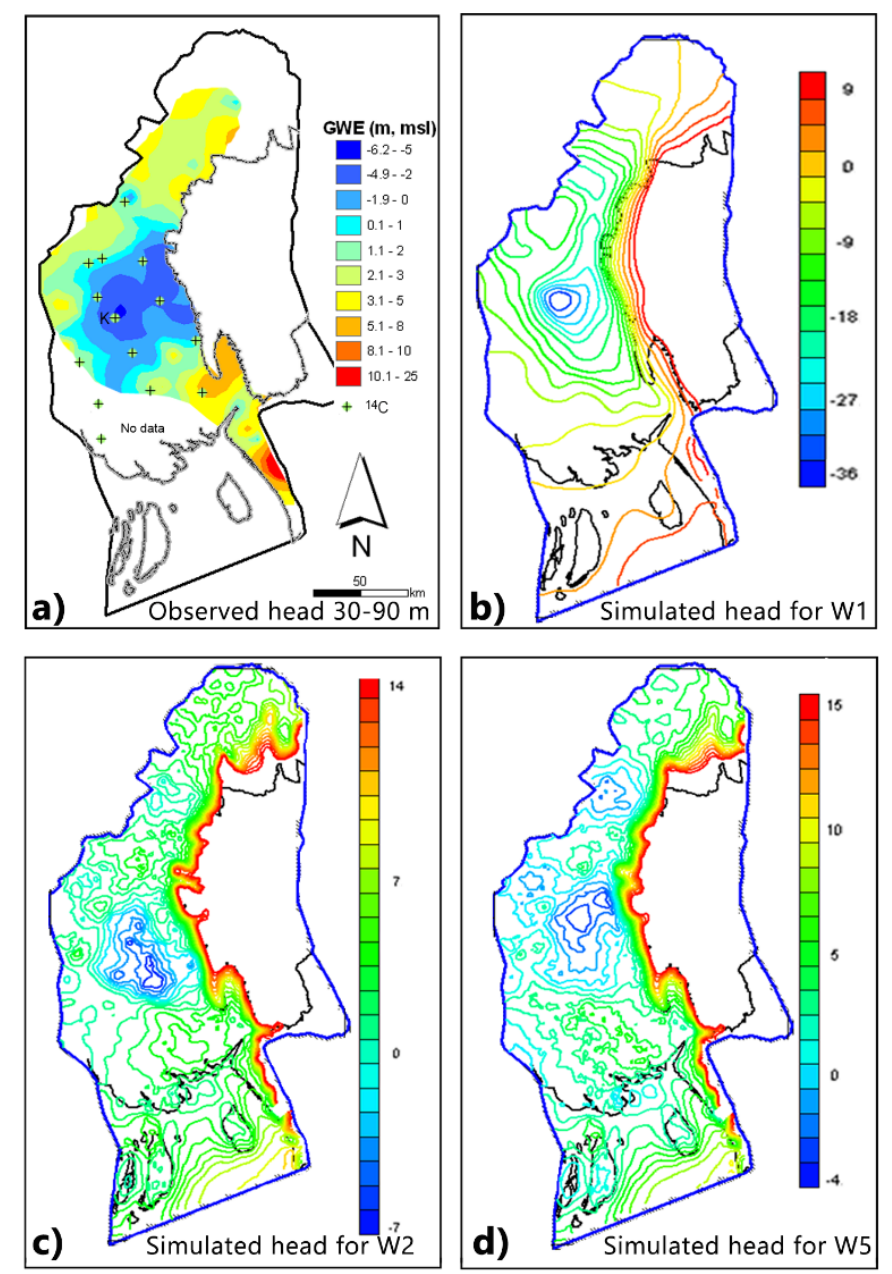

Fig. 7. Comparison of spatial patterns of observed and simulated hydraulic heads: (a) Elevation of groundwater table (GWE) (BADC measurement depth between 30 and-90 mbgl) in reference to MSL calculated for the model area based on water-table configuration, and SRTM elevation (EROS 2002). A water-table depression in the central part of the model area can be observed. Sample location for 14C used for location reference. Simulated head fields: (b) Model representation W1 (single layer homogeneous anisotropic aquifer), (c) Model representation W2 (single layer heterogeneous anisotropic aquifer), (d) Model representation W5 (4-layer heterogeneous anisotropic aquifer). 


\subsubsection{Head}

Hydraulic heads are conventionally used for groundwater model calibration (e. g., Freeze and Cherry, 1979; Kresic, 2007). Head data over the study area is largely restricted to measurements by the Bangladesh Water Development Board (BWDB) at shallow depths (median depth $<30 \mathrm{~m}$ ), and the Bangladesh Agricultural Development Corporation (BADC) has a limited number of wells to monitor groundwater head at the depths of irrigation abstraction, 30 to $90 \mathrm{mbgl}$, still in the shallower part of the aquifer system (BADC, 2004). All the models adequately reproduce the spatial pattern of shallow head distribution (Figure 7). The W1 homogeneous aquifer reproduction of shallow heads is uniformly low, but no further differentiation of the model performances was made on the basis of head, given that the main interest is in flow to the deeper levels of the aquifer, where head data is not available. Instead, groundwater travel times have been used as the primary basis for judgement of model performance, by comparison against independently-derived groundwater ages from the aquifer to depths up to $336 \mathrm{~m}$.

\subsubsection{Travel time versus groundwater ages}

It is known that a groundwater model may be acceptable by reference to heads but inadequate by reference to travel times and flow paths (e.g., Harrar et al., 2003; Troldborg et al., 2007; Zyvoloski et al., 2003). All the models, W1-W5, were used here to calculate travel time from points of recharge to 19 grid-blocks within the model domain (of which four are $<100 \mathrm{~m}$ deep), corresponding to locations of available ${ }^{14} \mathrm{C}$ groundwater age determinations.

A Pearson correlation analysis has been carried out to establish the extent of a linear relationship between the groundwater age and the modelled travel-times. All the models give a significant correlation, $r \geq 0.5$ (Figures 8,9), except W3 (the 4-layer, anisotropic and heterogeneous aquifer with a correlation length, $l_{i}=100 \mathrm{~m}$ applied to each layer) for which $\mathrm{r}$ is 0.32 . Model representation W5 (the 4-layer anisotropic and heterogeneous aquifer, with correlation length, $1_{i}=100 \mathrm{~m}$ (upper layer), $500 \mathrm{~m}$ (middle layer) and $1000 \mathrm{~m}$ (lower layer) respectively) gives the best correlation between groundwater age and modelled travel time $(\mathrm{r}=0.66, \mathrm{p}<0.05)$, followed by model representation W2 (the single layer anisotropic and spatially heterogeneous aquifer) for which $\mathrm{r}=0.61, \mathrm{p}<0.05$.

In all model representations, the best-fit line was also compared with the 1:1 line. It is seen that model representations W1 (the single layer anisotropic and homogeneous aquifer) and W2 (the single layer anisotropic and heterogeneous aquifer) have good agreement on this basis (slope, $m>0.9$ ), and are parallel to but non-coincident with the 1:1 line.

For all model representations the 19 groundwater age determinations were divided by the respective model estimated travel time and the median values of the age/model ratios were identified as an indicator of overall accuracy (Figure 8). A median value close to or equal to unity is expected. A median value greater than unity indicates a general under-estimation of travel time, while a value less than unity represents a general 
over-estimation. By this method it is apparent that model representations with higher values of anisotropy (W1) over-estimate the travel time, while representations incorporating extreme heterogeneity with spatially varied anisotropy (W4) under-estimate the travel-time.

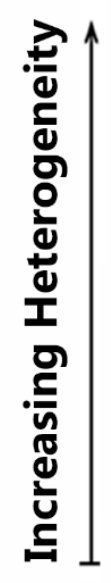

(a)

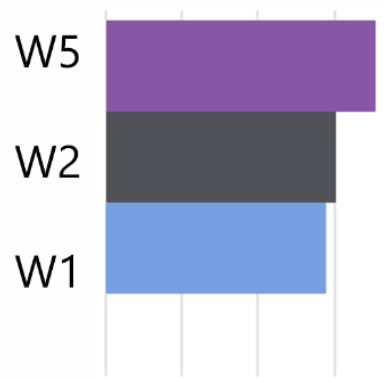

$\begin{array}{lllll}0 & 0.2 & 0.4 & 0.6 & 0.8\end{array}$

Correlation (b)

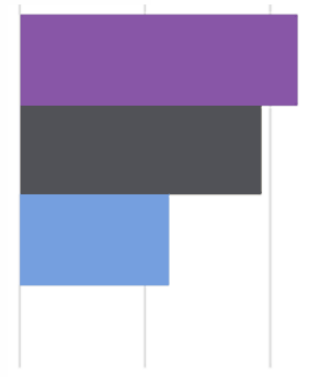

0.5

(c)

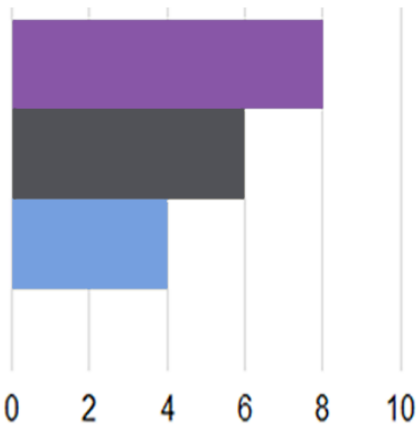

Median of Ratio

Number of Ages

W5 4-layer vertically and spatially heterogeneous \& anisotropic

W2 Single layer vertically homogeneous, spatially heterogeneous \& anisotropic

w1 Single layer homogeneous \& anisotropic

Fig. 8. Summary of comparison of groundwater age and travel time simulated by different model representations: a) Correlation between groundwater age and travel time, b) Median value of (groundwater age /travel time), c) Number of travel time equal to groundwater age. Cartoons of hydraulic conductivity fields are illustrated for easy visualisation.

A close look at the individual results, however, reveals that the models do not reproduce individual ${ }^{14} \mathrm{C}$ ages correctly. The plots of groundwater ages vs. the simulated travel-time show a great amount of scatter about the 1:1 line (Figure 9). Discrepancies can be compounded by the fact that travel-time to a point in space is an integration of the entire upstream velocity field, so that errors in calculated velocities can accumulate along a modelled flow path (Sanford et al., 2004). Comparisons have, however been made according to which model representation gives the greatest number of travel-time estimates within $\pm 25 \%$ of the groundwater age determination. This large range was allowed as a compensation of the effects of the aforesaid errors, and other considerations considered in the Discussion below. For this analysis a value of 100 years has been assigned to the 'modern' groundwater (in terms of ${ }^{14} \mathrm{C}$ activity). It is found that model representation W5 (vertically and spatially heterogeneous, anisotropic aquifer) successfully simulates travel times most frequently (Figure 8). 


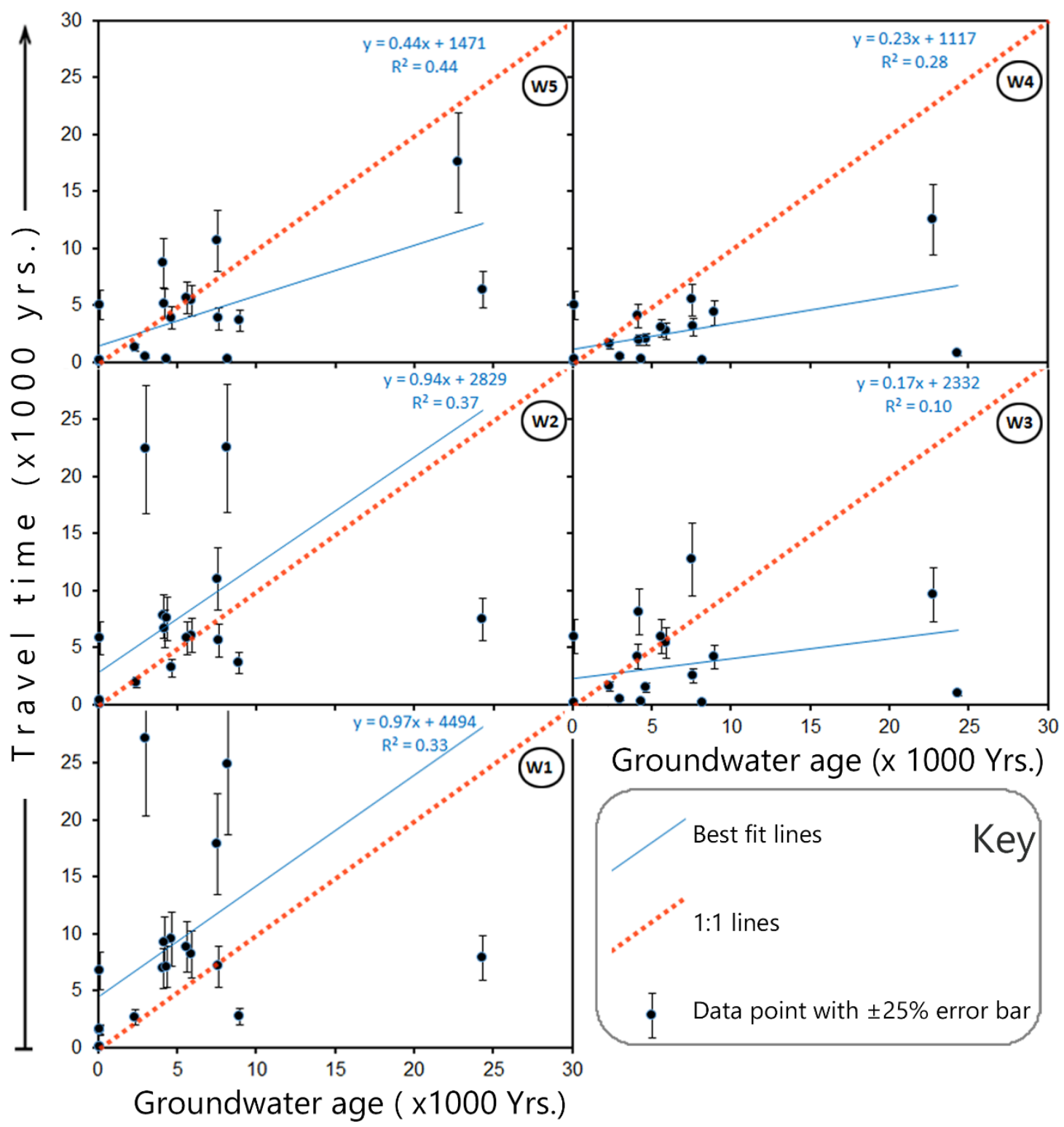

Fig. 9. Scatter plot of groundwater age vs travel time. In the graphs best fit lines and 1:1 lines are shown. Note the $\pm 25 \%$ error bar in the travel-time axis. There are some travel times in some representations greater than $30 \mathrm{ka}$ and they are not shown on the graph but are included in the analysis.

\section{Discussion}

\subsection{Hydrostratigraphy and representation of heterogeneity}

Analysis of the lithological framework of the aquifer (Figure 4) indicates that there is no regional separation by low-permeability material between a shallower and a deeper part of the aquifer, a similar observation to that recorded for the western part of the basin in West Bengal, India (Mukherjee et al., 2007b) by which the 
aquifer was classified as a single interconnected aquifer system trending to a multi-aquifer in the coastal areas. This concept was also supported by Burgess et al. (2010) at the basin scale. The hydraulic anisotropy due to the ubiquitous presence of interleaved low-permeability layers (i.e., finer hydrofacies) can lead to separate flow systems of a hierarchical nature (Hoque et al., 2017), by which deep groundwater is a part of the regional flow system (Burgess et al., 2010; Hoque et al., 2017; Khan et al., 2019; Michael and Voss, 2009b; Sikdar et al., 2018) separated from the shallow groundwater circulation. The distinctions drawn in vertical profile between hydraulic head (Khan et al., 2016; Ravenscroft et al., 2018; Zheng et al., 2005), groundwater age (Hoque and Burgess, 2012) and groundwater chemistry (Halim et al., 2010; Hoque and Burgess, 2012; Mukherjee et al., 2007a; Ravenscroft et al., 2018) may be the result of these distinct flow systems.

The entire sequence overlying the UMS is made of fluvio-deltaic sediments, deposited in channel-interfluve settings (McArthur et al., 2008) and with associated heterogeneity. The topography on the UMS surface is a result of geological folding in the region leading to change in depositional environment. In such a setting, deposits are characterised by channel-fill sands and floodplain deposits leading to curvilinear stacked sand bodies (i.e., channel-fill sands) which extend all the way to the surface in some areas. Equivalent channelfill sands were previously documented on seismic sections at greater depths between ca. 800 and $2000 \mathrm{~m}$ (Alam et al., 2003; Lindsay et al., 1991). The position of the sand-dominant channel-fill features changes over the depth slices, e.g., N-S palaeo-channels apparent in the 200-300 m interval change orientation to E$\mathrm{W}$ at shallower levels, possibly indicating a response to eustatic changes over the Quaternary (Figure SI6). In some areas, stacking of channel sands produces a direct connection between shallower and deeper levels of the aquifer system. At the Holocene high-stand, fine deposits overlie incised channel-fill sand deposits of the previous low stand because during the Holocene, channel migration, avulsion and crevasse splay continuously modified the inter-channel floodplain environment (Goodbred et al., 2003).

Hydraulically, sedimentary strata are conventionally grouped into multiple layers and designated as aquifers or aquitards according to their hydraulic conductivity (Freeze and Cherry, 1979), and a generalised numerical conversion may be applied for modelling purposes to achieve the effective hydraulic representation. However, in a fluvial-deltaic terrain such as in the Bengal Basin, heterogeneity and spatial discontinuity of the layers complicate the procedure. In this case, the hydraulic conductivity of a depth slice can vary spatially over several orders of magnitude, so heterogeneity is a major control on the bulk aquifer 'effective' properties on a regional scale. The major problem in modelling groundwater flow in this heterogeneous system is the scale of characterisation of the low-permeability layers as their number, frequency and arrangement control the hydraulic circulation (e.g., as shallow and deep flow systems); the strength of this circulation is unknown but is vulnerable to disruption by pumping as the physical barrier between the flow systems is not continuous (Hoque et al., 2017). Hydraulic short-circuiting could 
potentially lead to invasion of arsenic or other pollutants from the shallow flow systems to the deeper. Improved understanding and characterisation of the silt-clay layers will strengthen assessment of the sustainable pumping regimes.
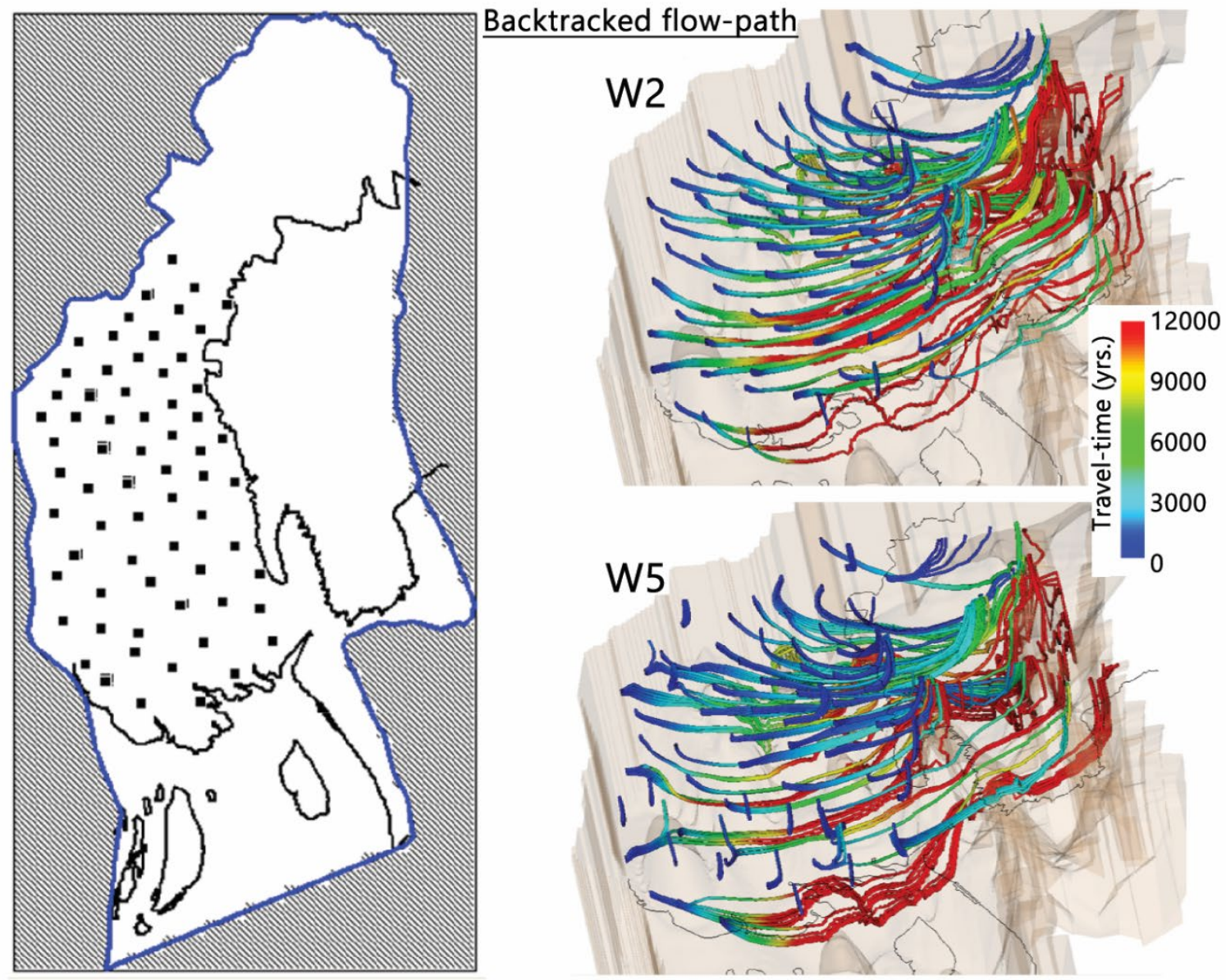

Fig. 10. Flow-paths tracked backward from the grid-location marked on the left figure at 210 to $250 \mathrm{~m}$ depth for the best model representations W2 and W5. Colour bar indicates the travel-time in years.

\subsection{Groundwater age and travel time}

The comparison of modelled groundwater travel time and groundwater ages based on ${ }^{14} \mathrm{C}$ dating highlighted significant differences in the performance of the different aquifer representations (Figures 8 and 9). Factors that could contribute to discrepancy between the simulated travel-times and groundwater age determinations may include:

- Groundwater ages were determined for samples collected from a tube-well with screened volume 0.03 $\mathrm{m}^{3}$, while simulated travel time is the mean-travel time of no less than a $1.00 \mathrm{E} 7(1000 \times 1000 \times 10) \mathrm{m}^{3}$ model grid volume. Groundwater age in an alluvial aquifer is found to vary over the length of a well screen (Sanford et al., 2004; Weissmann et al., 2002), however studies on the travel-time variation on 
the scale of a model grid are rare. Sanford and Buapeng (1996) discussed the importance of model discretisation to include individual sand and clay layers for capturing travel-time variability, though this is not possible in complex alluvial aquifers and in a sub-regional model

- Although $\delta^{13} \mathrm{C}$ data were used by Hoque and Burgess (2012) in a simple correction of the ${ }^{14} \mathrm{C}$ ages, alternative corrections could give age variations of a few to several thousand years (Plummer et al., 1994). Another potential source of error is the loss of ${ }^{14} \mathrm{C}$ along the flow path by diffusion into clay layers, which may lead to a significant over-estimation of groundwater age in a multi-layered alluvial aquifer (Sanford, 1997; Sanford and Buapeng, 1996).

- Ages of groundwater at depth in the study area, which range between 3,000 and 8,000 years, indicate that these would have been affected by changes in the flow regime over this time. In this study sea-level is considered constant at its present day level throughout, but it has mostly been above the current level in the recent past. A detailed paleo-flow simulation would be required to capture the effect of sea-level changes. It has however been shown that sea-level-induced gradient changes affect deep flow much less than shallow flow systems due to delay in readjustment determined by the effective aquifer diffusivity (see Tóth, 1995; 2009).

Such uncertainties contribute to concerns in calibrating groundwater models, or comparing them, against groundwater age. However, keeping in mind these difficulties, we support the view suggested by Poeter and Anderson (2005) that a range of equally plausible models are needed to evaluate certain management strategies, and comparison with groundwater age can provide a useful framework against which to judge the performance of different aquifer representations.

\subsection{Parsimonious representation}

The performance of each model representation W1-W5 against the criteria for groundwater age and travel time is illustrated in (Figures 8 and 9). W5, the layered aquifer representation with variable correlation length, returns the greatest number $(n=8)$ of groundwater ages as travel times within the $\pm 25 \%$ acceptance level, with a median of the groundwater age to travel time ratio close to 1 . W2 also consistently outperforms the homogeneous representation W1 in reproduction of groundwater ages. Representation W2 is based on lithological analysis specifically from the study region, whereas representations W3-W5 incorporate vertical heterogeneity experimentally, applying values for the characteristic length parameter drawn from the range in literature analogues. Therefore W3-W5 carry less significance than W2 in their comparison with W1. These findings taken together emphasise heterogeneity as a critical feature in consideration of flow path details in groundwater models, and specifically for models addressing contaminant transport in the Bengal Basin. Spatial heterogeneity is clearly advantageous over a homogeneous representation, and vertical heterogeneity appears capable of providing additional improvement. A higher density of data is required to calculate effective hydraulic conductivity 
values for smaller measurement volumes (Schulze-Makuch et al., 1999). Groundwater flow, in reality, responds to individual silt-clay layers. In the case of multi-layer representations, W3 - W5, a higher density of lithological data may enable improved parameterisation in comparison to the single-layer representation W2. In the present case however, spatial heterogeneity within a single layer aquifer system in which vertical lithological variation is incorporated as $\mathrm{Kh} / \mathrm{Kv}$ anisotropy is identified as the most parsimonious representation (e.g., Voss, 2011). A homogeneous isotropic representation is insufficient to return observed heads successfully, and incorporation of heterogeneities in a more complex manner than in W2 is not justified by the model performances.

\subsection{Groundwater source provenance and transboundary nature}

The balance of recharge origin, from local to distant, varies between the different aquifer representations (Figures 10 and SI7, S1.1), yet all the models indicate that shallow ( $<100 \mathrm{~m}$ deep) groundwater is dominantly derived from local recharge and a local origin of deep groundwater occurs when the surface topography and the model structure allows (W5 in Figures 10 and W3 in SI7).

For the model representations W2, and W5, the more successful representations with respect to groundwater age simulation, flow-paths from many points between 210 to $250 \mathrm{~m}$ depths in a high resolution grid were simulated back towards their recharge location. Both models show water at depth coming predominantly from hilly areas along the eastern margin of the basin, in Indian Territory (Figure 10). Management of the deep groundwater in this transboundary context provides additional challenges (Eckstein, 2011).

\subsection{Future groundwater development and resource security}

The high lithological variability of the BAS makes direct representation of heterogeneities in the models impossible, therefore representation of the effective hydraulic properties by upscaling is necessary (Michael and Voss, 2009b). The multi-model approach presented here can be applied to selecting the most effective and parsimonious approach to incorporating aquifer heterogeneity, for applications relating to groundwater development. For this purpose the models could be calibrated explicitly with respect to ${ }^{14} \mathrm{C}$ dates, and improved by consideration of additional groundwater age determinations. However, preferential flow and optimising a fully calibrated model was beyond the scope of the study. An alternative approach to represent heterogeneity in the Bengal Basin using geostatistics (Khan et al., 2016; Michael and Khan, 2016) successfully captures the effects of preferential vertical flow paths, of great significance in assessments of vulnerability of the deep groundwater to contamination from shallow regions of the aquifer.

Note that the analysis presented here demonstrates that groundwater at depth in the study area has always, under pre-development conditions, been recharged from the basin margin (Hoque et al., 2017); this is an advantageous basis supporting the security of the deep groundwater resource. There are some locations in the south of the study area where groundwater at depth is simulated as originating in part from a shallower 
depth in the local area. This finding may be an error associated with poor representation of the geology due to a low density of data, but the possibility remains that locally-induced recharge might transport arsenic and/or salinity from the shallow depth and ultimately compromise the security of deep groundwater abstraction at these points.

There is a need for monitoring of deep groundwater abstractions. Precursors of arsenic breakthrough to deep wells can be expected, for instance salinity where this occurs at an intermediate depth. Salinity would be expected to precede arsenic for two reasons, its intermediate depth of origin and its greater mobility in comparison to arsenic, for which retardation by sorption might be substantial (Radloff et al., 2011). Note that salinity is only patchily present, at intermediate depth, in the study area (Hoque et al., 2003), and is also present as isolated pockets in deeper parts (BWDB, 2005; Zahid et al., 2018). Therefore, the mobilisation of salinity from low permeability zones at depth in the aquifer may complicate its use as a monitoring precursor. Monitoring of $\mathrm{Cl} / \mathrm{Br}$ ratios (Hoque et al., 2014b; McArthur et al., 2012) and tritium/CFCs (Lapworth et al., 2018) on a decadal scale may also be indicative of a contribution to deep groundwater abstraction from shallow regions of the flow system.

\section{Acknowledgement}

M.A.H. gratefully acknowledges support (BDCS-2006-37) from the Commonwealth Scholarship Commission. We are grateful to the organizations DPHE, LGED, and BWDB of the Government of Bangladesh, for provision of lithological records. We would like to thank Kazi Matin Ahmed for helpful discussion when the model was being developed. We also thank two anonymous reviewers for constructive and helpful reviews.

\section{References}

Ababou, R., 1996. Random porous media flow on large 3-D grids: numerics, performance, \& application to homogenization. In: Wheeler, M.F. (Ed.), Mathematics \& application: Environmental studies - mathematical, computational and statistical analysis. IMA volume in Mathematics \& its application. Springer-Verlag, New York, pp. 1-25.

Aggarwal, P.K. et al., 2000. A report on isotope hydrology of groundwater in Bangladesh: implications for characterization and mitigation of arsenic in groundwater, International Atomic Energy Agency (IAEA), Vienna.

Ahmed, K.M., 2003. Constraints and issues of sustainable groundwater exploitation in Bangladesh, Proceedings of the International Symposium on Safe and Sustainable Exploitation of Soil \& Groundwater Resources in Asia, Okayama University, Japan, pp. 44-52.

Ahmed, M.F. et al., 2006. Ensuring safe drinking water in Bangladesh. Science, 314: 1687-1688. 
Al-Salek, J.A., 1998. Coastal trapping and funneling effects on storm surges in the Meghna estuary in relation to cyclones hittin Noakhali-Cox's Bazar coast of Bangladesh. Journal of Physical Oceanography, 28: 227-249.

Alam, M., Alam, M.M., Curray, J.R., Chowdhury, M.L.R., Gani, M.R., 2003. An overview of the sedimentary geology of the Bengal basin in relation to the regional tectonic framework and basin-fill history. Sediment. Geol., 155: 179-208.

BADC, 2003. Survey report on irrigation equipment and irrigated area in Boro 2003 season, Survey and Monitoring Project for Development of Minor Irrigation, Bangladesh Agricultural Development Corporation (BADC), Dhaka.

BADC, 2004. Groundwater Zoning Map (2004). Bangladesh Agricultural Development Corporation (BADC), Dhaka.

BADC/MMI/HTS, 1992. Deep Tubewell II Project, esp. vol 2.1 Natural Resources, , Mott MacDonald International (MMI) and Hunting Technical Services (HTS) for the Bangladesh Agricultural Development Corporation (BADC) under the assignment to the Overseas Development Administration (UK), BADC, Dhaka, Bangladesh.

BBS, 2004. Statistical year book of Bangladesh. Bangladesh Bureau of Statistics (BBS), Ministry of Planning, GoB, Dhaka.

BGS/DPHE, 2001. Arsenic contamination of groundwater in Bangladesh. WC/00/19, Department of Public Health Engineering (DPHE) of Government of Bangladesh and British Geological Survey (BGS) Keyworth.

Bhattacharya, P., Chatterjee, D., Jacks, G., 1997. Occurrence of arsenic-contaminated groundwater in alluvial aquifers from the Delta Plains, eastern India: Options for safe drinking water supply. Water Resources Development, 13: 79-92.

Bhuiyan, S.I., 1984. Groundwater use for irrigation in Bangladesh: the prospects and some emerging issues. Agricultural Administration, 16: 181-207.

Burgess, W.G. et al., 2010. Vulnerability of deep groundwater in the Bengal Aquifer System to contamination by arsenic. Nature Geosci., 3(2): 83-87.

BWDB, 2005. Report on deep aquifer characterization and mapping project, phase I (Kachua, Chandpur), Ground Water Hydrology Division-I, Bangladesh Water Development Board (BWDB), Dhaka.

Dhar, R.K. et al., 1997. Groundwater arsenic calamity in Bangladesh. Current Science, 73: 4859.

Domenico, P.A., Schwartz, F.W., 1998. Physical and Chemical Hydrogeology. John Wiley \& Sons, New York.

DPHE/BGS, 2001. Arsenic contamination of groundwater in Bangladesh. WC/00/19, Department of Public Health Engineering (DPHE) of Government of Bangladesh and British Geological Survey (BGS) Keyworth.

DPHE/BGS/MML, 1999. Groundwater studies for Arsenic contamination in Bangladesh. Phase I: Rapid Investigation., Department of Public Health Engineering (DPHE) of Government of Bangladesh, British Geological Survey (BGS) and Mott MacDonald Ltd (MML) UK.

DPHE/DANIDA, 2001. Hydrogeology summary report Department of Public Health Engineering (DPHE) and Danish International Development Assistance (DANIDA), Dhaka.

DPHE/DFID/JICA, 2006. Development of deep aquifer database and preliminary deep aquifer map, Department of Public Health Engineering (DPHE), UK Department for 
International Development (DFID) and Japan International Cooperation Agency (JICA), Ground Water Circle, DPHE, Dhaka, Bangladesh

Eckstein, G.E., 2011. Managing buried treasure across frontiers: the international Law of Transboundary Aquifers. Water International, 36(5): 573-583.

EPC/MMP, 1991. Dhaka region groundwater and subsidence study, Engineering and Planning Consultants (EPC) in association with Sir Mott MacDonald and Partners (MMP). Dhaka Water Supply and Sewerage Authority, Dhaka, Bangladesh.

EROS, 2002. Shuttle Radar Topography Mission (SRTM) Elevation Data Set. National Aeronautics and Space Administration (NASA), German Aerospace Center (DLR), Italian Space Agency (ASI). . The National Center for Earth Resources Observations and Science (EROS), United State Geological Survey (USGS) Sioux Falls, USA.

Fendorf, S., Michael, H.A., van Geen, A., 2010. Spatial and Temporal Variations of Groundwater Arsenic in South and Southeast Asia. Science, 328(5982): 1123-1127.

Fogg, G.E., 1986. Groundwater flow and sand body interconnectedness in a thick, multipleaquifer system. Wat. Resour. Res., 22(5): 679-694.

Freeze, R.A., Cherry, A.J., 1979. Groundwater. Prentice-Hall International (UK) Limited, London.

Gani, M.R., Alam, M.M., 1999. Trench-slope controlled deep-sea clastics in the exposed lower Surma Group in the southeastern fold belt of the Bengal Basin, Bangladesh. Sediment. Geol., 127: 221-236.

Goodbred, S.L., Jr., Kuehl, S.A., Steckler, M.S., Sarker, M.H., 2003. Controls on facies distribution and stratigraphic preservation in the Ganges-Brahmaputra delta sequence. Sediment. Geol., 155(3-4): 301-316.

GWTF, 2002. Report of the Ground Water Task Force (GWTF), Local Government Division, Ministry of LGRD \& Cooperatives, GoB, Dhaka.

Halim, M.A. et al., 2010. Evaluation of processes controlling the geochemical constituents in deep groundwater in Bangladesh: Spatial variability on arsenic and boron enrichment. Journal of Hazardous Materials, 180(1-3): 50-62

Harbaugh, A.W., 1990. A computer program for calculating subregional water budgets using results from the U. S. Geological Survey modular three-dimensional ground-water flow model. Open-File Report 90-392, U. S. Geological Survey, Reston, Virginia.

Harbaugh, A.W., Banta, E.R., Hill, M.C., McDonald, M.G., 2000. MODFLOW-2000, the US Geological Survey modular ground-water model - user guide to modularization concepts and the ground-water flow process, Open File Report 00-92. U. S. Geological Survey, Reston, Virginia, pp. 121.

Harrar, W.G., Sonnenborg, T.O., Henriksen, H.J., 2003. Capture zone, travel time, and solutetransport predictions using inverse modeling and different geological models. Hydrogeol. J., 11: 536-548.

Harvey, C.F. et al., 2006. Groundwater dynamics and arsenic contamination in Bangladesh. Chem. Geol., 228: 112-136.

Harvey, C.F. et al., 2002. Arsenic mobility and groundwater extraction in Bangladesh. Science, 298: 1602-1606.

Hoque, M., Hasan, M.K., Ravenscroft, P., 2003. Investigation of Groundwater Salinity and Gas Problems in Southeast Bangladesh. In: Rahman, A.A., Ravenscroft, P. (Eds.), Groundwater resources and development in Bangladesh - background to the arsenic 
crisis, agricultural potential and the environment. Bangladesh Centre for Advanced Studies, University Press Ltd., Dhaka, pp. 373-390.

Hoque, M.A., Burgess, W.G., 2012. ${ }^{14} \mathrm{C}$ dating of deep groundwater in the Bengal Aquifer System, Bangladesh: implications for aquifer anisotropy, recharge sources and sustainability. Journal of Hydrology, 444-445: 209-220.

Hoque, M.A., Burgess, W.G., Ahmed, K.M., 2017. Integration of aquifer geology, groundwater flow and arsenic distribution in deltaic aquifers - A unifying concept. Hydrological Processes, 31(11): 2095-2109.

Hoque, M.A., Burgess, W.G., Shamsudduha, M., Ahmed, K.M., 2011. Delineating low-arsenic groundwater environments in the Bengal Aquifer System, Bangladesh. Appl. Geochem., 26(4): 614-623.

Hoque, M.A., McArthur, J.M., Sikdar, P.K., 2014a. Sources of low-arsenic groundwater in the Bengal Basin: investigating the influence of the last glacial maximum palaeosol using a 115-km traverse across Bangladesh. Hydrogeol. J., 22(7): 1535-1547.

Hoque, M.A., McArthur, J.M., Sikdar, P.K., Ball, J.D., Molla, T.N., 2014b. Tracing recharge to aquifers beneath an Asian megacity with $\mathrm{Cl} / \mathrm{Br}$ and stable isotopes: the example of Dhaka, Bangladesh. Hydrogeol. J., 22(7): 1549-1560.

HU/NPD, 2001. Bangladesh petroleum potential and resources assessment 2001., Hydrocarbon Unit (HU), Ministry of Energy and Mineral Resources, GoB and Norwegian Petroleum Directorate (NPD), Dhaka.

Jia, Y. et al., 2018. Distribution, formation and human-induced evolution of geogenic contaminated groundwater in China: A review. Sci. Total Environ., 643: 967-993.

Jones, P.H., 1985. Geology and groundwater resources of Bangladesh, P. H. Jones Hydrogeology Inc., Baton Rouge, LA, USA.

Khan, M.R. et al., 2016. Megacity pumping and preferential flow threaten groundwater quality. Nature Communications, 7: 12833.

Khan, M.R. et al., 2019. High-Arsenic Groundwater in the Southwestern Bengal Basin Caused by a Lithologically Controlled Deep Flow System. Geophysical Research Letters, 46(22): 13062-13071.

Konikow, L.F., Kendy, E., 2005. Groundwater depletion: A global problem. Hydrogeol. J., 13(1): 317-320.

Kresic, N., 2007. Hydrogeology and Groundwater Modeling. CRS Press, Taylor \& Francis Group, Boca Raton.

Lapworth, D.J. et al., 2018. Security of Deep Groundwater in the Coastal Bengal Basin Revealed by Tracers. Geophysical Research Letters, 45(16): 8241-8252.

Lindsay, J.F., Holiday, D.W., Hulbert, A.G., 1991. Sequence stratigraphy and the evolution of the Ganges-Brahmaputra complex. American Association of Petroleum Geologist Bulletin, 75: 1233-1254.

McArthur, J.M. et al., 2008. How paleosols influence groundwater flow and arsenic pollution: A model from the Bengal Basin and its worldwide implication. Wat. Resour. Res., 44: W11411.

McArthur, J.M., Sikdar, P.K., Hoque, M.A., Ghosal, U., 2012. Waste-water impacts on groundwater: $\mathrm{Cl} / \mathrm{Br}$ ratios and implications for arsenic pollution of groundwater in the Bengal Basin and Red River Basin, Vietnam. Sci. Total Environ., 437(0): 390-402. 
Michael, H.A., Khan, M.R., 2016. Impacts of physical and chemical aquifer heterogeneity on basin-scale solute transport: Vulnerability of deep groundwater to arsenic contamination in Bangladesh. Advances in Water Resources, 98: 147-158.

Michael, H.A., Voss, C.I., 2008. Evaluation of the sustainability of deep groundwater as an arsenic-safe resource in the Bengal Basin. PNAS, 105(25): 8531-8536.

Michael, H.A., Voss, C.I., 2009a. Controls on groundwater flow in the Bengal Basin of India and Bangladesh: regional modeling analysis. Hydrogeol. J., 17(7): 1561-1577.

Michael, H.A., Voss, C.I., 2009b. Estimation of regional-scale groundwater flow properties in the Bengal Basin of India and Bangladesh. Hydrogeol. J., 17(6): 1329-1346.

MPO, 1987. The groundwater resources and its availability for development, Harza Engineering USA in association with Sir MacDonald and Partners, UK, Met Consultant, USA and EPC Ltd., Dhaka.

Mukherjee, A., Fryar, A.E., 2008. Deeper groundwater chemistry and geochemical modeling of the arsenic affected western Bengal basin, West Bengal, India. Appl. Geochem., 23(4): 863-894.

Mukherjee, A., Fryar, A.E., Rowell, P.D., 2007a. Regional-scale stable isotopic signatures of recharge and deep groundwater in the arsenic affected areas of West Bengal. Journal of Hydrology, 334: 151-161.

Mukherjee, A., Fryar, A.E., Rowell, P.D., 2007b. Regional hydrostratigraphy and groundwater flow modeling of the arsenic affected western Bengal basin, West Bengal, India. Hydrogeol. J., 15(7): 1397-1418.

Nilsson, B., Højberg, A.L., Refsgaard, J.C., Troldborg, L., 2007. Uncertainty in geological and hydrogeological data. Hydrology and Earth System Sciences, 11: 1551-1561.

ORNL, 2008. LandScan ${ }^{\mathrm{TM}} 2006$ Global Population Dataset - compiled on a 30" X 30" latitude/longitude grid. . Oak Ridge National Laboratory (ORNL), U.S. Department of Energy, Oak Ridge, TN 37831, USA, www.ornl.gov/landscan.

Plummer, L.N., Preston, E.C., Parkhurst, D.L., 1994. An interactive code (NETPATH) for modelling net geochemical reactions along a fow-path, Version 2.0, US Geological Survey

Poeter, E., Anderson, D., 2005. Multimodel ranking and inference in ground water modeling. Ground Water, 43(4): 597-605.

Poeter, E., Gaylord, D.R., 1990. Influence of Aquifer Heterogeneity on Contaminant Transport at the Hanford Site. Ground Water, 28(6): 900-909.

Pollock, D.W., 1994. User's guide for MODPATH/MODPATHPLOT, version 3: a particle tracking post-processing package for MODFLOW, the US Geological Survey finitedifference ground-water flow model U. S. Geological Survey Open-File Report 94-464.

Radloff, K.A. et al., 2011. Arsenic migration to deep groundwater in Bangladesh influenced by adsorption and water demand. Nature Geosci., 4: 793-798.

Rahman, A.A., Ravenscroft, P. (Eds.), 2003. Groundwater resources and development in Bangladesh - background to the arsenic crisis, agricultural potential and the environment. Bangladesh Centre for Advanced Studies, University Press Ltd., Dhaka, 446 pp.

Rahman, M.M., Hussain, M.A., Islam, G.M.T., Haque, M.A., Hoque, M.M., 2004. Hydromorphological characteristics around the Meghna bridge site in the Meghna river, Institute of Water \& Flood Modelling (IWFM), Bangladesh University of Engineering \& Technology (BUET), Dhaka. 
Ravenscroft, P., 2003. Overview of the hydrogeology of Bangladesh. In: Rahman, A.A., Ravenscroft, P. (Eds.), Groundwater resources and development in Bangladesh background to the arsenic crisis, agricultural potential and the environment. Bangladesh Centre for Advanced Studies, University Press Ltd., Dhaka, pp. 43-86.

Ravenscroft, P., Brammer, H., Richards, K.S., 2009. Arsenic pollution: a global synthesis. Wiley-Blackwell, U. K., 616 pp.

Ravenscroft, P., Burgess, W.G., Ahmed, K.M., Burren, M., Perrin, J., 2005. Arsenic in groundwater of the Bengal Basin, Bangladesh: Distribution, field relations, and hydrogeological setting. Hydrogeol. J., 13: 727-751.

Ravenscroft, P., McArthur, J.M., Rahman, M.S., 2018. Identifying multiple deep aquifers in the Bengal Basin: Implications for resource management. Hydrological Processes, 32(24): 3615-3632.

Reimann, K.-U., 1993. Geology of Bangladesh. Gebrüder Borntraeger, Berlin-Stuttgart, 160 pp.

Renard, P., de Marsily, G., 1997. Calculating equivalent permiability: a review. Advances in Water Resources, 20(5-6): 253-278.

Richts, A., Struckmeier, W.F., Zaepke, M., 2011. WHYMAP and the Groundwater ResourcesMap of the World 1:25,000,000. In: Jones, J.A.A. (Ed.), Sustaining Groundwater Resources-A Critical Element in the Global Water Crisis, International Year of Planet Earth. Springer Science+Business Media B.V. 2011, pp. 159 - 173.

Sanford, W., 2002. Recharge and groundwater models: an overview. Hydrogeol. J., 10(1): 110120.

Sanford, W., 2011. Calibration of models using groundwater age. Hydrogeol. J., 19(1): 13-16.

Sanford, W.E., 1997. Correcting for diffusion in carbon14 dating of ground water. Ground Water, 35(2): 357-361.

Sanford, W.E., Buapeng, S., 1996. Assessment Of A Groundwater Flow Model Of The Bangkok Basin, Thailand, Using Carbon-14-Based Ages And Paleohydrology. Hydrogeol. J., 4(4): 26-40.

Sanford, W.E., Plummer, L.N., McAda, D.P., Bexfield, L.M., Anderholm, S.K., 2004. Hydrochemical tracers in the middle Rio Grande Basin, USA: 2. Calibration of a groundwater-flow model. Hydrogeol. J., 12: 389-407.

Scanlon, B.R. et al., 2018. Global models underestimate large decadal declining and rising water storage trends relative to GRACE satellite data. Proceedings of the National Academy of Sciences.

Schulze-Makuch, D., Carlson, D.A., Cherkauer, D.S., Malik, P., 1999. Scale dependency of hydraulic conductivity in heterogeneous media. Ground Water, 37(6): 904-919.

Shamsudduha, M., Taylor, R.G., Chandler, R.E., 2015. A generalized regression model of arsenic variations in the shallow groundwater of Bangladesh. Wat. Resour. Res.: n/a-n/a.

Shibasaki, N., Lei, P., Kamata, A., 2007. Evaluation of deep groundwater development for arsenic mitigation in western Bangladesh. Environ. Sci. Health, Part A, 42(12): $1919-$ 1932.

Sikdar, P.K., Ghosal, U., Chakraborty, S., 2018. Groundwater modeling to understand the impact of pumping in the deep Late Pleistocene aquifers of the western Bengal Basin on arsenic migration. Arabian Journal of Geosciences, 11(24): 795.

Stute, M. et al., 2007. Hydrological control of As concentrations in Bangladesh groundwater. Wat. Resour. Res., 43: W09417.

Timani, B., Peralta, R., 2015. Multi-model groundwater-management optimization: reconciling disparate conceptual models. Hydrogeol. J., 23(6): 1067-1087. 
Tiwari, V.M., Wahr, J., Swenson, S., 2009. Dwindling groundwater resources in northern India, from satellite gravity observations. Geophysical Research Letters, 36(18): n/a-n/a.

Tóth, J., 1995. Hydraulic Continuity In Large Sedimentary Basins. Hydrogeol. J., 3(4): 4-16.

Tóth, J., 2009. Gravitational systems of groundwater flow: theory, evaluation, utilization. Cambridge University Press, Cambridge, 297 pp.

Troldborg, L., Refsgaard, J.C., Jensen, K.H., Engesgaard, P., 2007. The importance of alternative conceptual models for simulation of concentrations in a multi-aquifer system. Hydrogeol. J., 15: 843-860.

Umitsu, M., 1993. Late Quaternary sedimentary environments and landforms in the Ganges Delta. Sediment. Geol., 83: 177-186.

UNDP, 1982. The hydrogeological conditions of Bangladesh, Technical report DP/UN/BGD-74009/1, United Nations Development Programme (UNDP), Dhaka.

van Geen, A., Ahmed, K.M., Seddique, A.A., Shamsudduha, M., 2003. Community wells to mitigate the current arsenic crisis in Bangladesh. Bull. World Health Organ., 81: 632638.

Voss, C., 2011. Editor's message: Groundwater modeling fantasies - part 2, down to earth. Hydrogeol. J.: 1-4.

Wada, Y., Wisser, D., Bierkens, M.F.P., 2014. Global modeling of withdrawal, allocation and consumptive use of surface water and groundwater resources. Earth Syst. Dynam., 5(1): $15-40$.

Wahid, S.M., Babel, M.S., Gupta, A.D., Clemente, R.S., 2007. Spatial assessment of groundwater use potential for irrigation in Teesta Barrage Project in Bangladesh. Hydrogeol. J., 15(2): 365-382.

WARPO, 2000. National Water Management Plan (NWMP) - draft development strategy report, , Water Resources Planning Organization (WARPO), Ministry of Water Resources, GoB, Dhaka.

Weissmann, G.S., Zhang, Y., LaBolle, E.M., Fogg, G.E., 2002. Dispersion of groundwater age in an alluvial aquifer system. Wat. Resour. Res., 38(10): 1198-1210.

Wilson, C.A., Goodbred Jr., S.L., 2015. Construction and Maintenance of the GangesBrahmaputra-Meghna Delta: Linking Process, Morphology, and Stratigraphy. Annual Review of Marine Science, 7(1): null.

WWF, DoA, 2007. More rice, less water - small state, big results - experience of SRI in Tripura, India, WWF International, Gland, Switzerland, and Department of Agriculture (DoA), Government of Tripura, Agartala - 799 003, Tripura, India.

Zahid, A., Hassan, M.Q., Ahmed, K.M.U., 2015. Simulation of flowpaths and travel time of groundwater through arsenic-contaminated zone in the multi-layered aquifer system of Bengal Basin. Environmental Earth Sciences, 73(3): 979-991.

Zahid, A. et al., 2018. Analysis of the Aquifer Pumping Test Data to Determine the Deep Groundwater Security in the Southeastern Bangladesh.

Zheng, Y. et al., 2005. Geochemical and hydrogeological contrasts between shallow and deeper aquifers in the two villages of Araihazar, Bangladesh: Implications for deeper aquifers as drinking water sources. Geochim. Cosmochim. Acta, 69(22): 5203-5218.

Zhou, Y., Herath, H.M.P.S.D., 2017. Evaluation of alternative conceptual models for groundwater modelling. Geoscience Frontiers, 8(3): 437-443. 
Zyvoloski, G. et al., 2003. The site-scale saturated zone flow model for Yucca Mountain: calibration of different conceptual models and their impact on flow paths. J. Contam. Hydrol., 62-63: 731-750. 